\title{
Cretaceous-Quaternary seismic stratigraphy of the Tanga offshore Basin in Tanzania and its petroleum potential
}

\author{
Benatus Norbert Mvile ${ }^{1,2}$ (1) $\cdot$ Emily Barnabas Kiswaka ${ }^{3}$. Olawale Olakunle Osinowo ${ }^{4} \cdot$ Isaac Muneji Marobhe $^{3}$. \\ Abel Idowu Olayinka ${ }^{4}$ Elisante Elisaimon Mshiu $^{3}$
}

Received: 14 July 2021 / Accepted: 21 October 2021 / Published online: 1 November 2021

(c) The Author(s) 2021

\begin{abstract}
In this study, the available 2D seismic lines have been interpreted to understand the basin development and petroleum potential of the Late Cretaceous-Quaternary stratigraphy of the Tanga offshore Basin in Tanzania. Conventional seismic interpretation has delineated eight sedimentary fill geometries, fault properties, stratal termination patterns and unconformities characterizing the studied stratigraphy. The Late Cretaceous was found to be characterized by tectonic quiescence and uniform subsidence where slope induced gravity flows that resulted during the Miocene block movements was the major mechanism of sediment supply into the basin. The Quaternary was dominated by extensional regime that created deep N-S to NNE-SSW trending graben. The graben accommodated thick Pleistocene and Holocene successions deposited when the rate of tectonic uplift surpasses the rate of sea level rise. Thus, the deposition of lowstand system tracts characterized by debris flow deposits, slope fan turbidites, channel fill turbidites and overbank wedge deposits, known for their excellent petroleum reservoir qualities, especially where charged by Karoo Black Shales. Subsequent tectonic quiescence and transgression lead to the emplacement of deep marine deposits with characteristic seismic reflection patterns that indicate the occurrence of Quaternary shale sealing rocks in the study area. The occurrence of all the necessary petroleum play systems confirms the hydrocarbon generation, accumulations and preservation potential in the Tanga Basin.
\end{abstract}

Keywords Tanga Basin $\cdot$ Quaternary successions $\cdot$ Prograding clinoforms $\cdot$ Unconformity $\cdot$ Sedimentary fills $\cdot$ Channel fill

\section{Introduction}

An increase in the demand for hydrocarbon resources to fuel industrialization across the globe has led to the overexploitation of currently identified hydrocarbon reserves (IEA 2017). This has necessitated the need to investigate new unexplored/frontier basins to identify future reserves (Busygin et al. 2010). However, most of these frontier

Benatus Norbert Mvile

benimvile@yahoo.com

1 Pan African University, Life and Earth Sciences Institute (Including Health and Agriculture), Ibadan, Nigeria

2 Department of Physics, College of Natural and Mathematical Sciences, University of Dodoma, Postal Office Box 259, Dodoma, Tanzania

3 Department of Geology, University of Dar Es Salaam, Postal Office Box 35052, Dar es Salaam, Tanzania

4 Department of Geology, University of Ibadan, Ibadan 200284, Nigeria basins lack extensive geological and geophysical information to properly characterize them (Jacques et al. 2003, 2004; Mickus et al. 2009; Bastia et al. 2010; Blaich et al. 2010; Lentini et al. 2010; Uruski 2010; Ali et al. 2012; Becker et al. 2012; Dehler and Welford 2012; Pángaro and Ramos 2012; Houghton et al 2014). This challenge is more obvious in African countries where data confidentiality conditions imposed by foreign companies restrict local researchers from accessing key information to study potential areas for hydrocarbon exploration. For the case of Tanzania, lack of extensive seismic data covering her sedimentary basins has limited hydrocarbon exploration achievements in both onshore and offshore geological settings (Bosellini 1986; Wescott and Diggens 1998; Dapeng 2001; Roberts et al. 2012; Zhixin et al. 2015; Mkuu 2018). Lack of detailed information on the petroleum system of the basins means that not much is known about the basin's development, lithology, stratigraphy and its petroleum potential (Zhixin et al. 2015; Mkuu 2018; Mvile et al. 2020). To contribute to the ongoing exploration activities in Tanzania, the 
available 2D seismic data have been used in this study for investigation of the Cretaceous-Quaternary stratigraphy of the Tanga Basin for presence of key petroleum system elements. Tanga Basin is a coastal basin situated along portions of the East African coast with both onshore and offshore components (Fig. 1). Tanga onshore Basin covers most part of the Tanga region located in the north-eastern Tanzania (Fig. 1). Eastern limit of the basin is marked by a more or less N-S trending shoreline of the Indian Ocean while the NNE-SSW trending Tanga Fault marks the western limit of the basin. Duruma Basin in Kenya and Ruvu Basin in Tanzania form the northern and southern limits of the Tanga onshore Basin, respectively (Delvaux 2001; Wopfner 2002). The Tanga Fault separates the Neo Proterozoic basement rocks of the Mozambique Belt from the overlying sedimentary successions (Kapilima 2003; Mvile et al. 2020). Tanga offshore Basin covers the offshore part off the coast of Tanga region. The basin is dissected by several structural elements including Quaternary faults (Fig. 1).

Development of the Tanga Basin results from several extensional tectonic events that culminated in the breakup of the Gondwana Supercontinent (Zongying et al. 2013). These tectonic events influenced sedimentation in different basins in the continental margin settings of Somalia, Ethiopia,

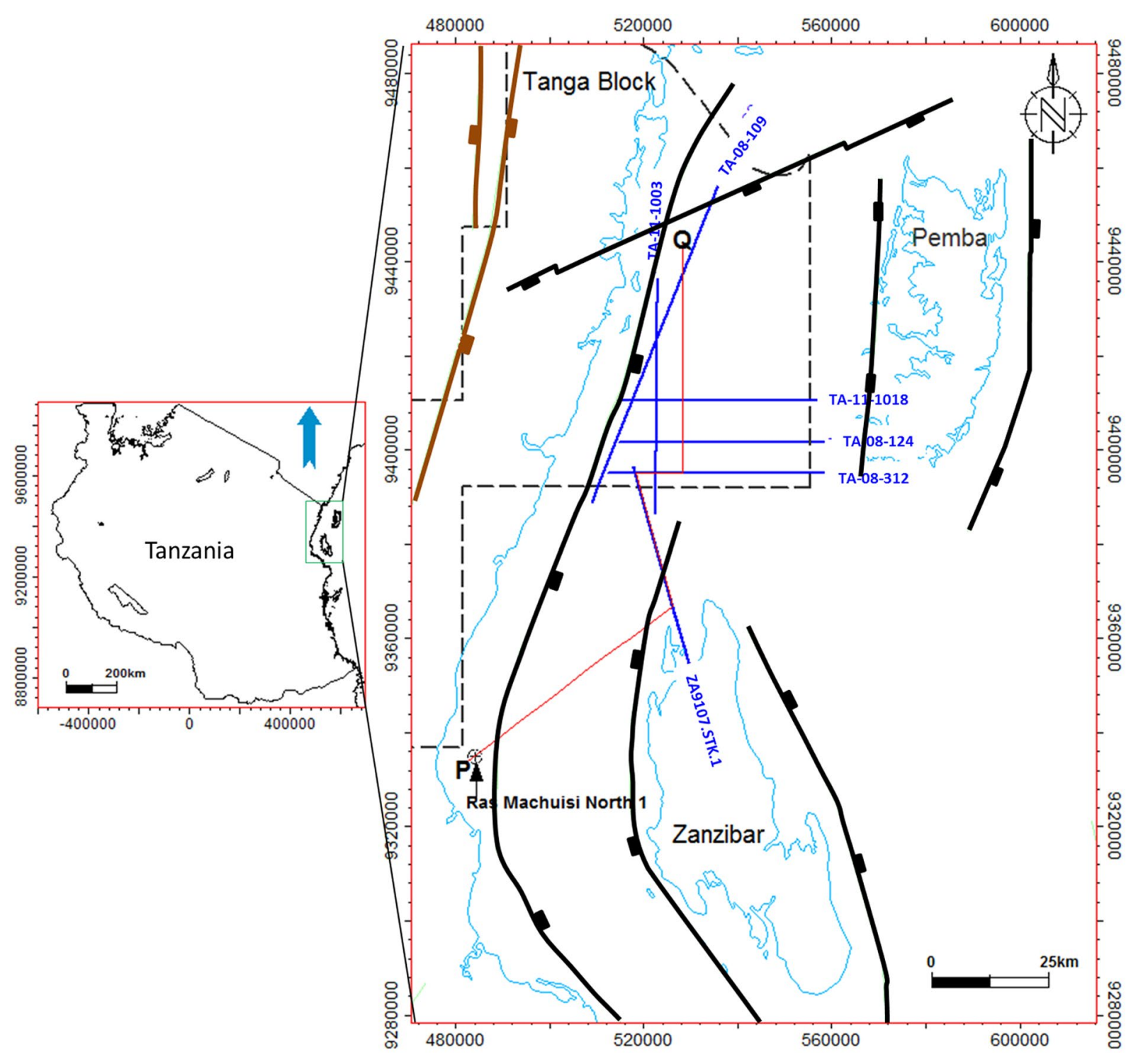

Fig. 1 Structural element map of the study area showing locations of key seismic lines and Ras Machuisi North 1 well used for assigning ages to the studied seismic intervals. Brown solid lines are the PermoTriassic faults while black solid lines are the Quaternary fault systems that have dissected the Sea Bottom. Structural elements were modi- fied from Kapilima (2003). Points P and Q mark the ends of a composite seismic line (red zigzag line) that was generated to assist age assignment to the studied successions. The WGS-84 UTM Zone 37S coordinate system has been used in this map 
Kenya, Tanzania, Mozambique and Madagascar (Zongying et al. 2013). The basins that resulted from the Gondwana breakup contain Mesozoic and Cenozoic clastic reservoirs and drift and marginal marine shales as potential cap rocks (Brownfield 2016). Despite the presence of several research works reporting tectono-sedimentary development of the offshore basins of East Africa, Cretaceous-Quaternary successions of the Tanga offshore Basin have been poorly studied and their petroleum potential is not well known (Zongying et al. 2013; Brownfield 2016; Mvile et al. 2020). This work was therefore aimed at improving an understanding of the Late Cretaceous-Quaternary tectono-sedimentary development, and assesses petroleum potential of the study area based on 2D qualitative seismic interpretation.

\section{Geologic setting}

\section{Tectonic development}

Sedimentary development of the offshore basins of East Africa has been influenced mostly by tectonics and partly by climate, sea level fluctuations, basin topography and syn-depositional interaction of down-slope gravity flows and along-slope bottom currents (Kent et al. 1971; Wopfner 2002; Kapilima 2003; Sansom 2018). Major tectonic events include the Permo-Triassic Karoo rifting which created several inland basins, Jurassic rifting and the East African Rift system during Cenozoic-recent times

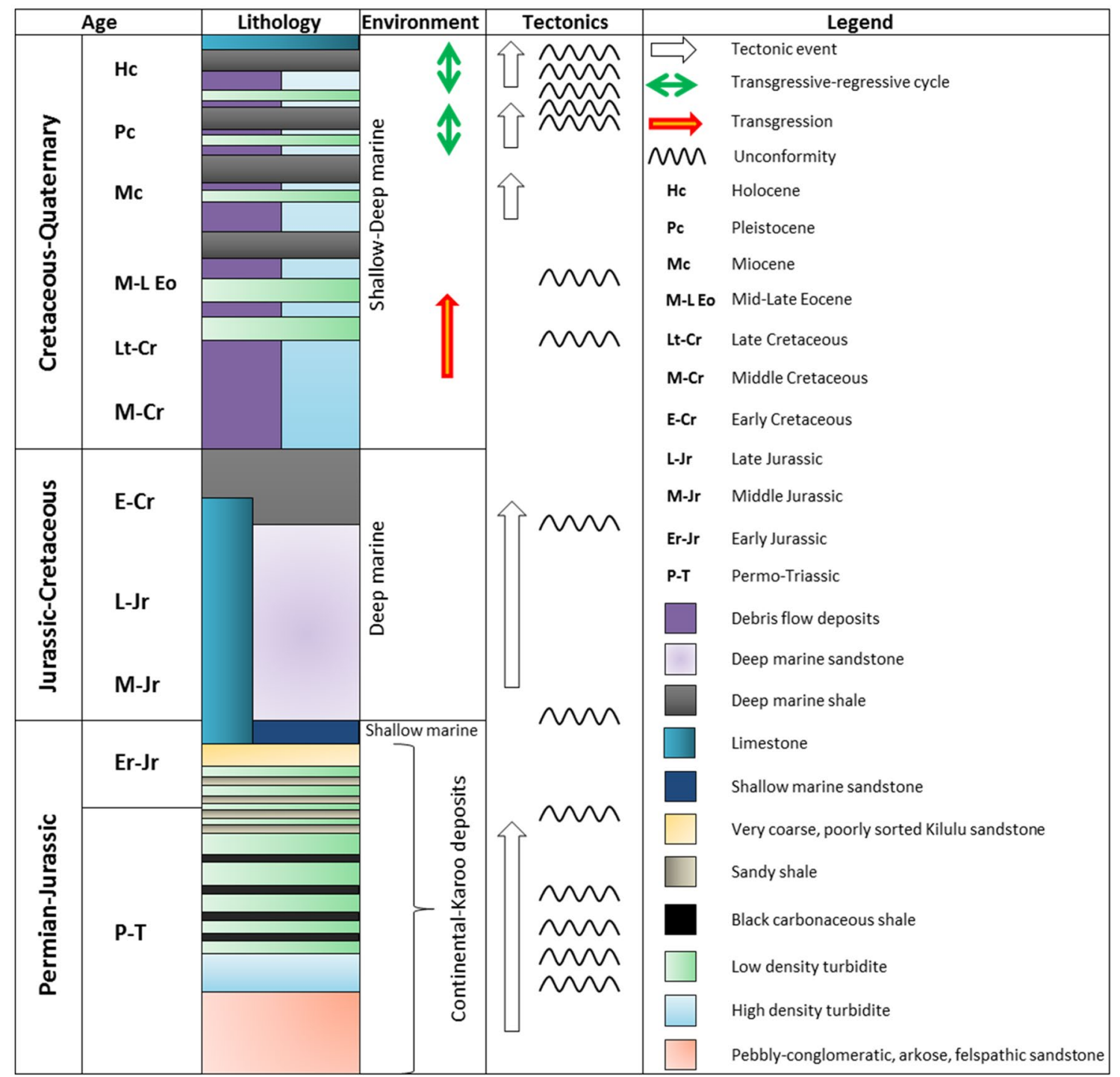

Fig. 2 Chronostratigraphic scheme of the Tanga Basin showing major extensional tectonic events, sea level fluctuations, depositional environments and unconformities characterizing the study area. Strati- graphic column and respective features have been modified after Seward (1922), Kent et al. (1971), TPDC (1992), Kapilima (2003), Mahanjane et al. (2014), Franke et al. (2015) and Magohe (2019)

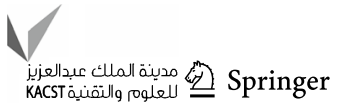


(Kapilima 2003; Fig. 2). Structural evolution of East Africa Rift system (EARs) followed old structural grains associated with fragmentation of the Gondwana Supercontinent (Franke et al. 2015). The EARs has two inland arms forming the western and eastern branches of the system. However, age equivalent rift features have been mapped off the coast of East Africa where up to $30 \mathrm{~m}$ wide, N-S trending compartmentalized rift basin exist (Ebinger et al. 1997; Foster et al. 1997; Franke et al. 2015). Wide variation of initiation ages of the EARs are reported in different places (Franke et al. 2015; Macgregor 2015). The oldest and the initial block movements were reported to occur in the Late Eocene-Oligocene, but several of initial offshore block movements began during Miocene-Pliocene time (Franke et al. 2015; Macgregor 2015). Rapid rift subsidence and sedimentation in the offshore setting happened during Pliocene and Pleistocene (Franke et al. 2015). Most of the extensional rift features in the offshore EARs were formed during Pleistocene to Recent times (Franke et al. 2015). While the occurrence of the highlighted tectonic elements has been presented in a regional context, this study has presented the exact locations of the preserved Cretaceous-Quaternary tectonic features in the Tanga offshore Basin.

\section{Stratigraphy of the study area}

There is no formal stratigraphic subdivision that has been established for the Tanga Basin (Magohe, 2019). Informally, the basin stratigraphy is hereby subdivided into three major depositional intervals with varying characteristics (Fig. 2). These are the Permian-Jurassic Karoo successions, Jurassic-Cretaceous marine deposits and Cretaceous-Quaternary successions. Part of the Cretaceous-Quaternary successions off the coast of East Africa was deposited during the Late Cretaceous transgression that reached its maximum during the Eocene (Key et al., 2008; Franke et al., 2015; Fig. 2). The stratigraphy of the Tanga Basin is characterized by several unconformities (Kent et al. 1971; TPDC 1992; Magohe 2019; Fig. 2).

\section{Karoo successions}

Deposition of the Karoo sediments began by emplacement of poorly sorted, pebbly-conglomeratic, arkose and felspathic continental sandstones outcropping near Tanzania-Kenya border (Seward 1922; Kapilima 2003). The basal conglomeratic sandstone is overlain by localized high density turbidites which resulted from episodic gravity failures. Low density turbidites alternating with thin deformed black carbonaceous shales, deposited during intervening quiet periods, follow upward. The carbonaceous black shales, with abundant plant remains, have high organic content (Seward 1922; Kreuser et al. 1990; Magohe 2019) and are exposed on the dry beds of River Kakindu in Gombero village, Tanga. The upper part of the Karoo interval in the Tanga Basin is dominated by low density turbidites characterized by alternating sandstone layers and sandy shales forming tail deposits of the system (Seward 1922). Localized, very coarse, poorly sorted sandstones also form part of the upper Karoo interval (Seward 1922). Karoo age equivalent evaporites, alternating with organic rich claystones, have been documented in the Mandawa Basin in the southern part of the Tanzania coastal basin (Kapilima 2003).

\section{Jurassic-cretaceous successions}

Karoo sedimentation took place under continental environments (Fig. 2) with localized marine incursions along the coast (Kent et al. 1971; Kapilima 2003). The Karoo regime was followed by shallow marine deposition during the Early Jurassic (Fig. 2). The entire coastal area was overwhelmed by marine conditions during the Middle-Late Jurassic leading to the development of stable carbonate platform in the study area. The Tanga limestones and their age equivalent deep marine shales and sandstones (Fig. 2) were deposited during this time period. The Cretaceous sediments consist of sandstones, shales and limestones with the Cretaceous sandstones dominating most of the reservoirs in the Tanzania coastal basins (Mbede 1991; Kapilima 2003).

\section{Late cretaceous-quaternary successions}

The Late Cretaceous-Quaternary seismic stratigraphy has been studied in order to understand the development of the basin and its petroleum potential. The interval consists of debris flow deposits and turbidites that occurred as part of the lowstand slope fan and channel fill deposits. The debris flows were deposited mostly during the block movements that triggered episodic gravity flows. These intervals are overlain by deep marine deposits interpreted to be hemipelagic shales deposited during the periods of relative sea level rise. Quaternary carbonates are also present along the shores of the Indian Ocean in Tanga beaches (Fig. 2).

\section{Dataset and methodology}

Eight (8) 2D seismic sections were interpreted using Petrel application software to improve the understanding of the sedimentary system of the offshore Tanga Basin. Three of the seismic lines were acquired along E-W trending profiles, two each along NE-SW and N-S profile lines while one section was established along NW-SE trending profile (Fig. 1). The Ras Machuisi North 1 well situated near the southernmost edge of the Tanga block, (Fig. 1), which penetrated up 


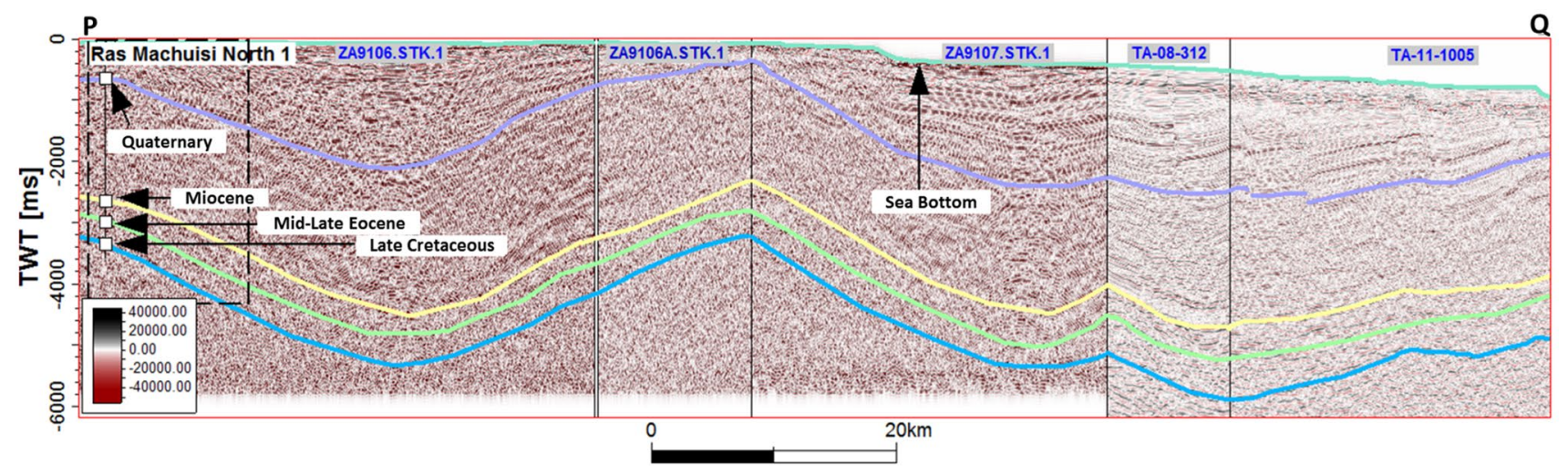

Fig. 3 A composite seismic line, tied to Ras Machuisi North 1 well, showing laterally extensive major reflectors namely Late Cretaceous, MidLate Eocene, Miocene, Quaternary and Sea Bottom. Location of this line is shown by solid red line P-Q on Fig. 1

to the Late Cretaceous interval (Fig. 3) was used to assign ages to the five major seismic reflectors mapped from the seismic sections. The reflectors were found to be Late Cretaceous, Mid-Late Eocene, Miocene, Quaternary and Sea Bottom markers (Fig. 3). Seismic to well tie technique (Fig. 4), comprising of sonic log calibration, generation of synthetic seismogram and tying time calibrated seismic reflectors and depth measure geologic rock formation was employed to assign ages to the delineated seismic reflectors. The Sonic $\log$ used to accomplish this task was calculated by using Gardner equation. The synthetic generation process encountered slight mismatch due to the absence of well logs in the shallow part of the hole; this likely generated some degree of uncertainty in the correct wavelet and possibly processing errors. Specific characteristic seismic expressions allowed extensive lateral tracing of the major reflectors. Figure 3 is a

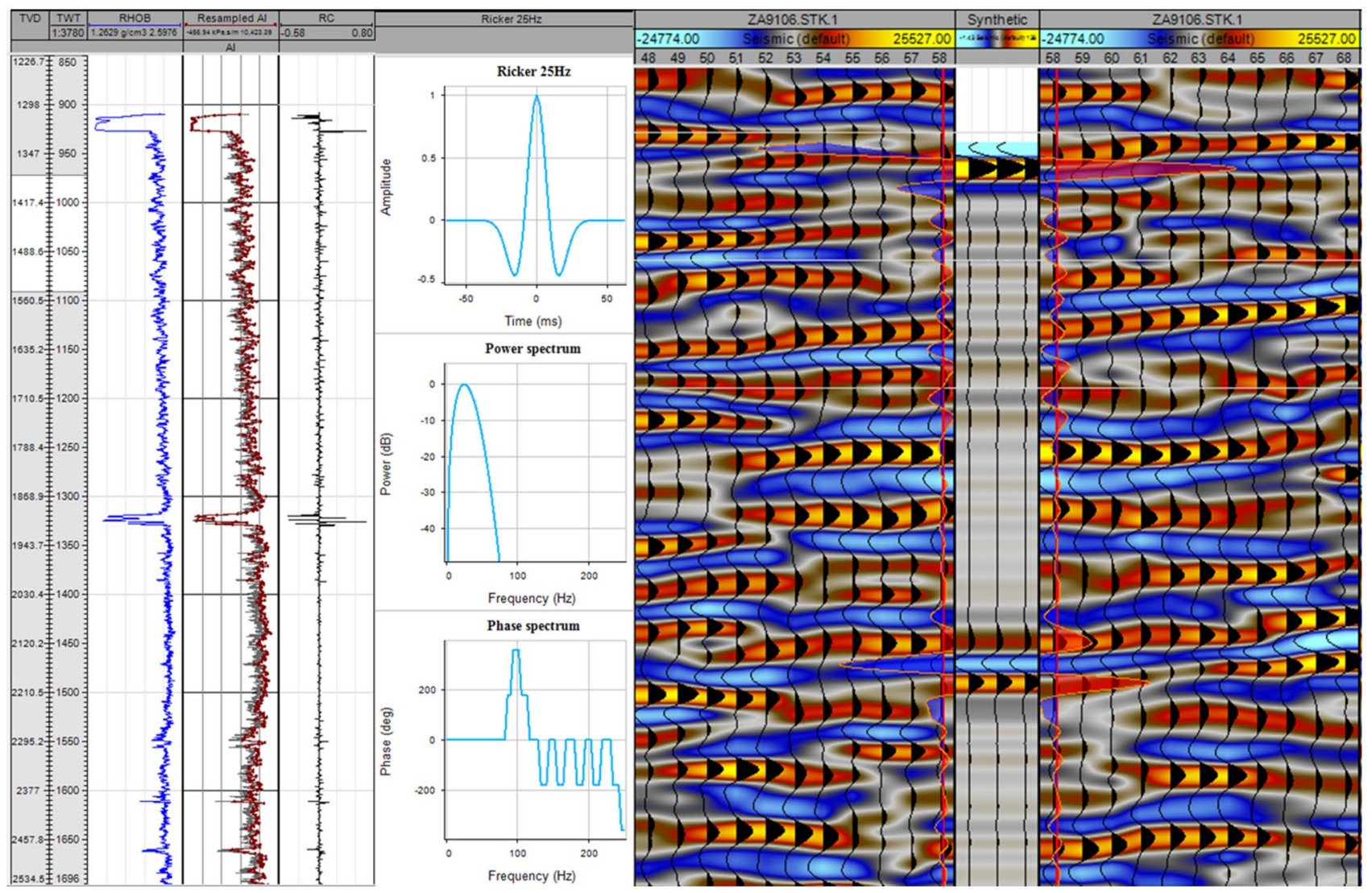

Fig. 4 Part of synthetic seismic profile generated to facilitate well tie (Fig. 3) aimed at assigning ages to the studied seismic interval

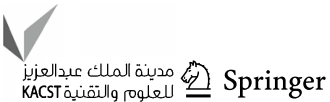


composite seismic line generated to assist age control of the studied succession in the study area. This was done because it was not possible to access a wellbore that intercepts the seismic line(s) in the area of interest. Ages of other reflectors and respective sedimentary packages were assigned tentatively based on their seismic stratigraphic positions relative to the known five markers. Seismic geometries of sedimentary bodies, palaeodepositional basin shapes, stratal relationships and termination patterns (for example angular erosional truncations, onlap and downlap) were used to identify unconformities which bound different depositional regimes. The geometries of sedimentary fills, stratal termination patterns, internal seismic expressions and basin shapes were interpreted based on the works of Mitchum et al. (1977), Vail (1987), Prosser (1993), Nøttvedt et al. (1995), Ravnås and Bondevik (1997), Posamentier et al. (2000), Posamentieier and Kolla (2003), Armitage et al. (2012), Braathen et al. (2012), Kyrkjebø et al. (2004) and Kiswaka and Felix (2020). The unconformities presented herein were identified based on the original definitions by Mitchum et al. (1977) and recent works of Kyrkjebø et al. (2004) and Kiswaka and Felix (2020). The use of the term unconformity follows previous explanations of the seismic expression of the stratigraphy off the coast of East Africa (Franke et al. 2015; Kiswaka 2015; Fonnesu et al. 2020). Surface and depth contour maps were used to establish structural orientation and identification of thick sedimentary successions that may have a petroleum potential (e.g. Ali et al. 2019a, b; Ali 2020). Similar techniques will also be employed to accomplish this work.

\section{Results and interpretations}

\section{Sedimentary fills and seismic reflectors}

Based on observed seismic reflections, their termination patterns and ages, basinal fill geometries and perceived palaeodepositional basin shapes, the following Cretaceous-Quaternary tectono-sedimentary development were identified in the Tanga offshore Basin.

\section{Sedimentary fills}

Eight different sedimentary fills have been identified in the Tanga offshore Basin (Fig. 5). The fills together with their respective termination patterns and properties of internal reflectors were used to delineate the Late Cretaceous-Quaternary tectonic events and seismic facies characterizing stratigraphy of the studied interval.

Fill type A (Fig. 5a) consists of a relatively constant thickness sedimentary packages that have been discontinued by a fault. The packages are characterized by weak discontinuous internal reflectors. This fill type indicates that deposition took place during tectonic quiescence (see Kiswaka and Felix (2020)); faulting shows a post-fill tectonic deformation. Parts of the Late Cretaceous deposits of the Tanga offshore Basin are characterized by this fill type (Fig. 6).

Fill type B (Fig. 5b) is a gently dipping strata that onlap onto a base reflector, with characteristic chaotic internal reflection pattern deposited during massive input of clastic sediments (Braathen et al. 2012). The chaotic internal configuration suggests that debris flow deposits dominate the fill system and the onlapping surface marks an unconformity (Mitchum et al. 1977; Posamentier et al. 2000). The basal surface (unconformity) in this fill type is the Mid-Late Eocene reflector while the onlapping strata are Miocene in age (Figs. 7 and 8). This suggests rapid basinward sedimentation during Miocene and that the Mid-Late Eocene is an unconformity that resulted from erosion of Miocene gravity currents.

Fill type $\mathrm{C}$ is characterized by a wedge-shaped sedimentary package expanding toward the bounding fault (Fig. 5c). Internally, the fill type consists of depressions filled by localized, uniformly thick strata bounded by strong positive amplitude reflectors. Part of fill type $\mathrm{C}$ is discontinued by near vertical faults. The wedge-shaped sedimentary package suggests a post-rift infill of remnant rift topography (Nøttvedt et al. 1995), and the depressions are interpreted to show palaeochannel system that followed the fault system at a time when fault movement has stopped. Migration of the channels toward the right side of the cartoon is similar to seismic expression of channel evolution system reported by Armitage et al. (2012). This fill type is shown by some of the Miocene seismic intervals in the study area, thus the bounding fault is named Miocene fault (Fig. 9). The part of the fill type $\mathrm{C}$ deformed by near vertical faults is referred to as Quaternary faults because they can be traced up to the Sea Bottom (Fig. 10).

Fill type D (Fig. 5d) is also a wedge-shaped geometry containing two sections (lower and upper parts) but with different arrangement of internal strata. The lower part is characterized by gently dipping internal strata that thicken toward the bounding fault. The upper part contains internal strata that are characterized by a more or less constant thickness. This fill type, which is shown in some of the Miocene intervals of the Tanga offshore Basin (Fig. 6), is overlain by a relatively continuous reflector that blanket the wedgeshaped sub-basin. Sedimentary packages above the blanket are more or less parallel. Presence of two sections within a wedge suggests that the depocenter was filled in two stages linked to fault activity. The lower pattern indicates that Miocene sedimentation took place during active faulting, i.e. syn-rift deposition (Nøttvedt et al. 1995; Ravnås and Bondevik 1997; Ravnås and Steel 1998; Kiswaka and Felix 2020). The constant thickness of this unit implies that deposition took place after the fault movement has stopped, i.e. post-rift 

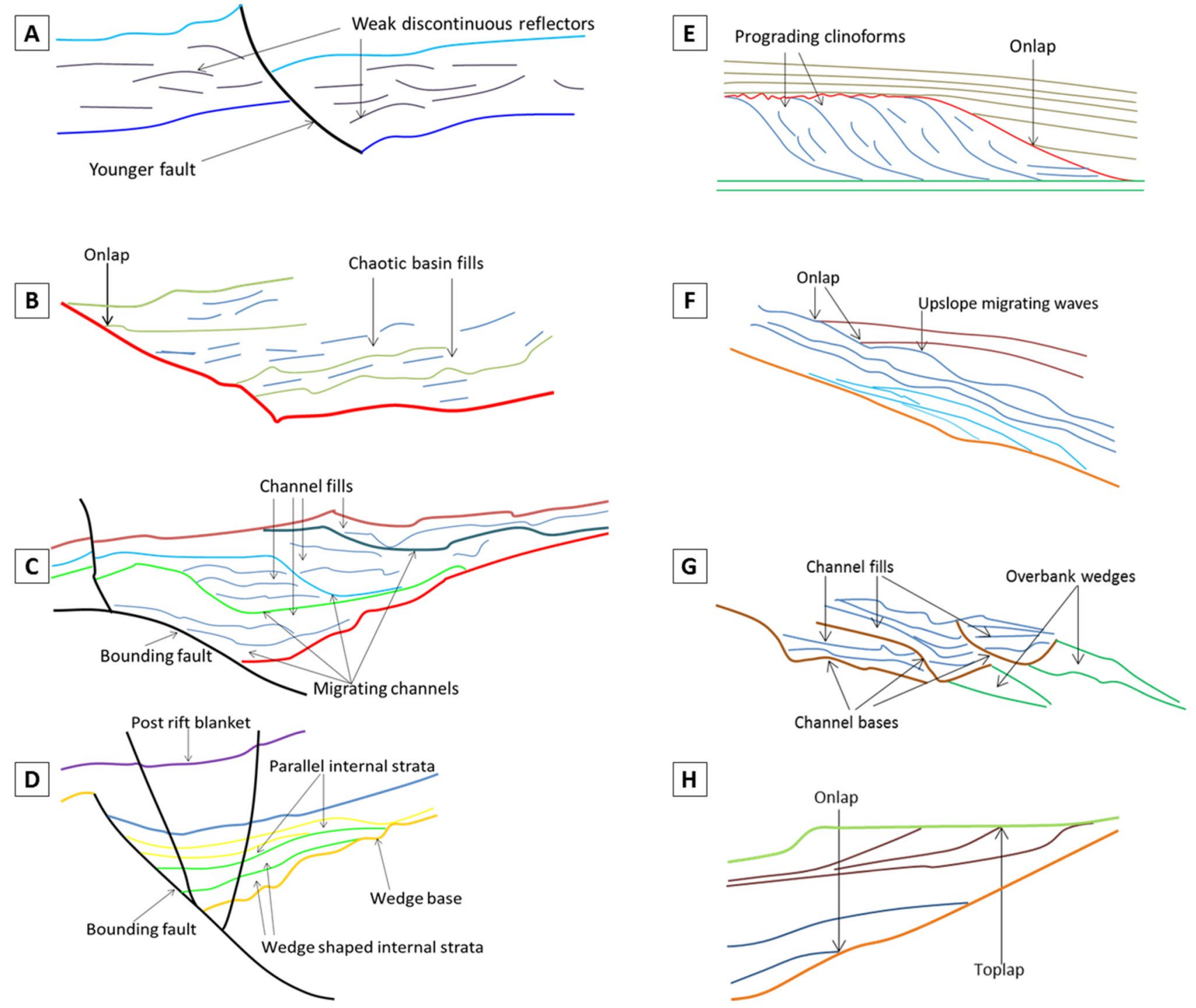

Fig. 5 Cartoons illustrating sedimentary fill types characterizing the Late Cretaceous-Quaternary stratigraphy of the Tanga offshore Basin

sedimentation (see Kiswaka and Felix 2020). Continuous reflector blanketing the wedge-shaped sub-basin marks complete infill of a remnant rift topography above which a new depositional configuration is established (Prosser 1993).

Fill type E (Fig. 5e) is composed of three major elements. Its base is marked by a near-parallel reflectors (first element) followed by moderate dipping clinoforms (second element) that have both chaotic and uniform internal seismic reflection patterns. The chaotic configurations are seen on the left side of the cartoon while clear sedimentary pattern is seen in the right side of the cartoon. The clinoforms onlap onto the near-horizontal basal surface and their top seismic boundary is both irregular and regular. This top boundary is an onlap surface for the immediate superjacent strata (lower part of the third element) that followed deposition of the clinoforms. These onlap terminations are stepping upslope until the top boundary of the clinoforms is blanketed by near parallel strata characterized by both weak and strong reflections. The prograding clinoforms suggest that deposition took place under low sea level environment at a time when there was a high influx of clastic sediments into the basin; mark a lowstand system tract (LST) (Vail 1987). The internal chaotic configurations of the clinoforms suggests debris flow deposits while clear sedimentary strata imply presence of turbidites (Figs. 11 and 12) in the distal part of the flow system. Generally, the LST was deposited farther into the basin while the overlying successions (third element) were deposited within the more proximal settings (Posamentier et al. 1991). The irregular and regular parts of the top seismic boundary of the clinoforms show that the reflectors are both unconformable in the proximal/shallow part of the 

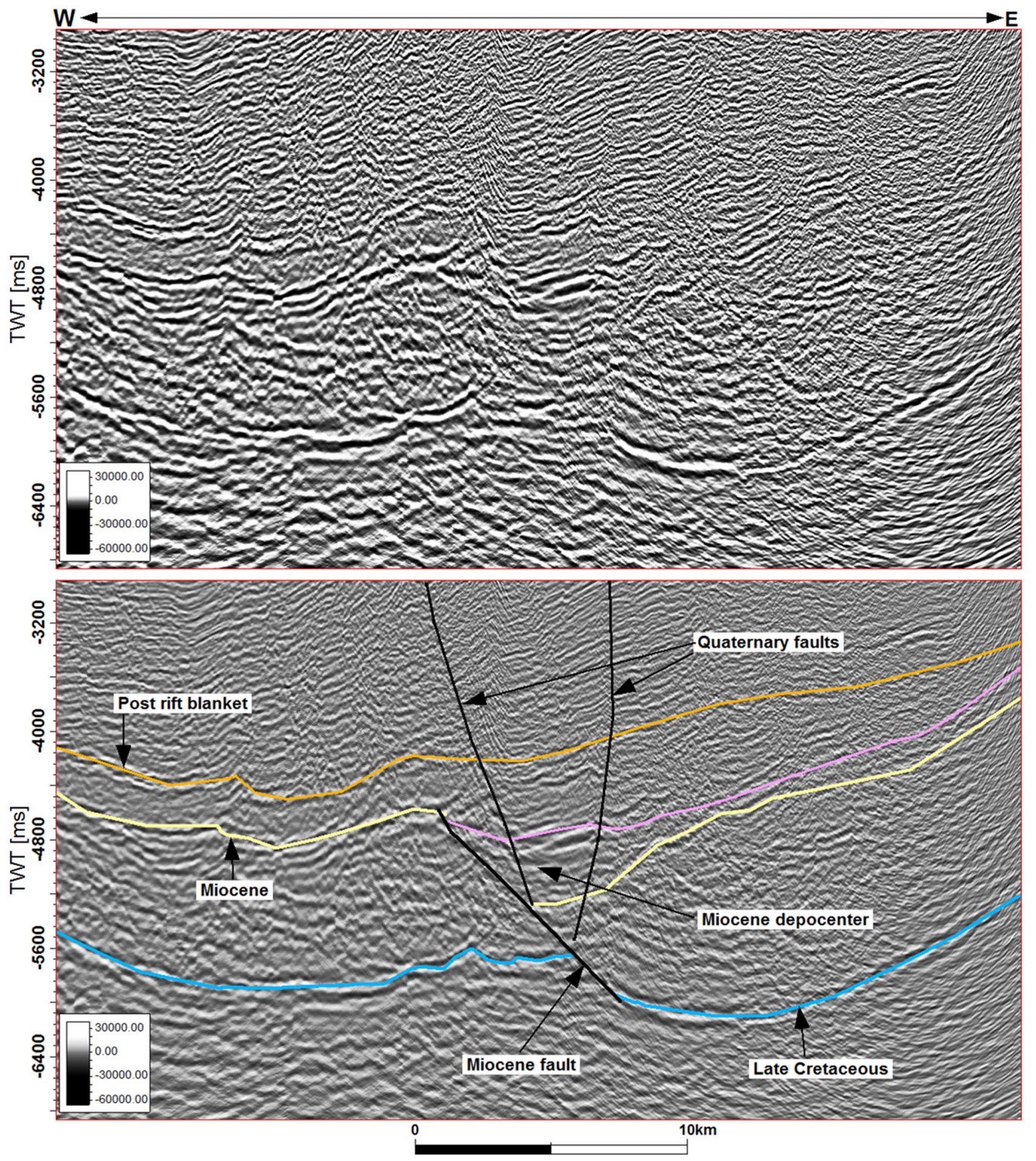

Fig. 6 Uninterpreted and interpreted seismic line TA-08-312 showing the laterally extensive Late Cretaceous and Miocene reflectors. Here Miocene fault is a moderately dipping, major discontinuity

basin and comformable in the deeper basinal areas, respectively. This boundary is a "sequence boundary" (SB) and it marks a transition from LST to highstand system tract (HST) (Vail 1987; Posamentier and Vail, 1988; Mitchum bounding Miocene depocenter while the Quaternary faults are near vertical discontinuities which have crosscut thick sedimentary successions

et al. 1977). Onlapping of the immediate superjacent strata onto the SB shows early stage of transgression. Further blanketing of the SB implies continued transgression and gradual decrease in coarse deposits (Posamentier et al.

\footnotetext{
1

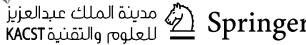



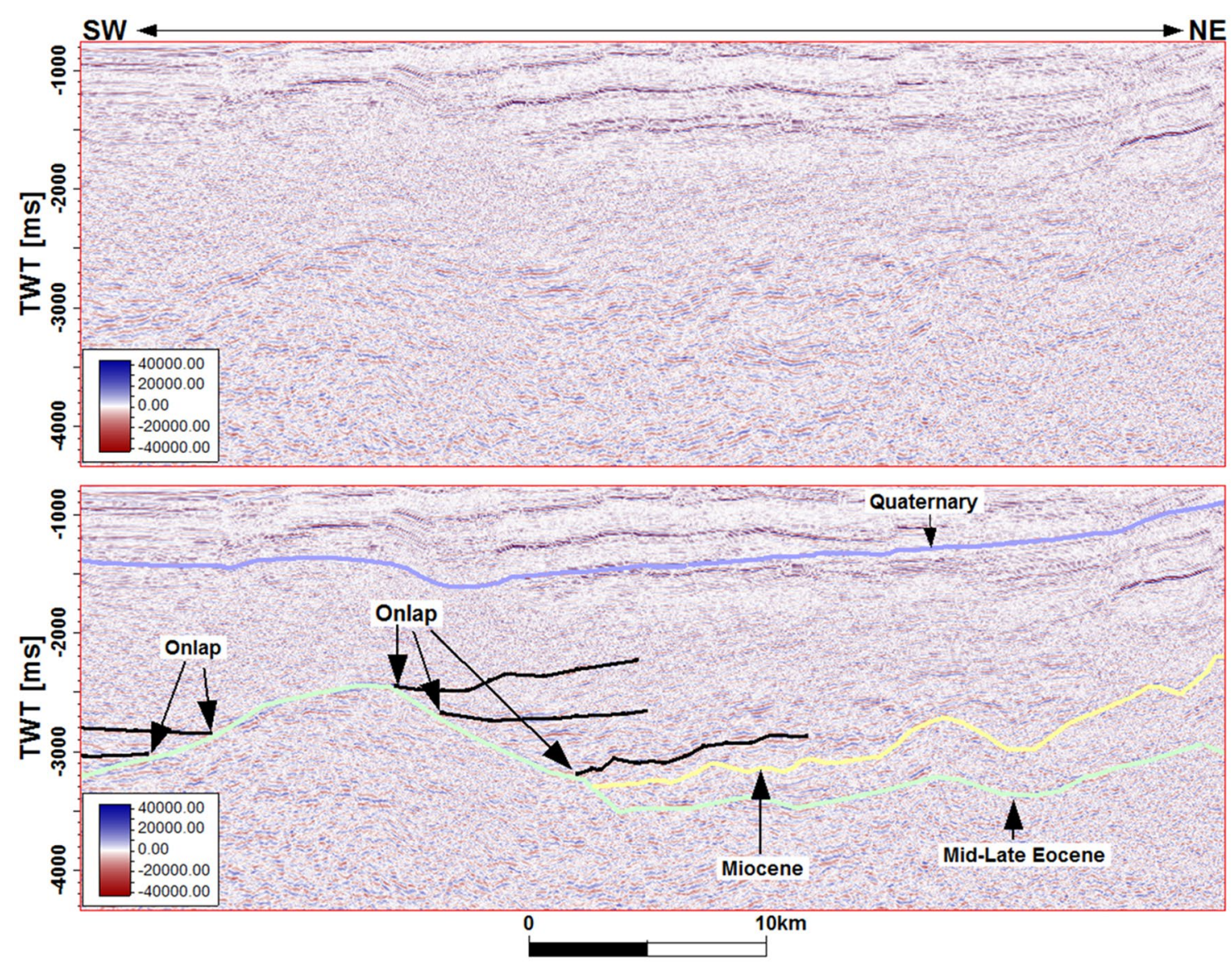

Fig. 7 Uninterpreted and interpreted seismic line TA-08-109 showing Miocene strata onlapping onto the Mid-Late Eocene reflector. Here sedimentary successions above the Quaternary reflector are characterized by strong negative reflections

2000). Fill type $\mathrm{E}$ was observed in some intervals of the Quaternary successions in the study area (e.g. Figure 11).

Fill type F (Fig. 5f) comprised of lower, middle and upper subunits. The lower part downlap onto the bottom boundary and characterized by distinct layering pattern which presents clear seismic reflections. The middle part is characterized by sinuous reflectors that seem to migrate upslope. Troughs marked by these sinuous reflectors are filled by deposits with transparent seismic manifestation. The upper part of this fill type is composed of sedimentary strata that onlap onto the wavy successions and the downlap termination pattern suggests basinward deposition (Vail 1987). Comparable successions are called lowstand slope fan deposits (Vail 1987) and that interpretation is adopted herein. Sedimentary successions in the lowstand slope fan deposits have high sand to mud ratios (Posamentier and Vail 1988). Clear layering with strong positive reflections indicates presence of high density turbidites in the lower part of the unit. Sinuous features similar to that of the middle part were identified in the Oligocene interval offshore southern Tanzania (Sansom 2018). Sansom (2018) interpreted these arrangements as upslope migrating sediment waves and considered them to be part of channel levee deposits. However, the features also resemble laterally isolated clinoforms and are hereby interpreted to mark LST deposits emplaced during limited clastic inputs. Transparent trough fills present muddy-deposits laid down during quiet periods that followed periodic gravity flows which emplaced the prograding clinoforms. Strata onlapping onto the sinuous interval marks the beginning of a transgressive regime that led to deposition of HST. Fill type F is seen in some of the Quaternary deposits at a relatively higher stratigraphic level than fill type E (Fig. 12) suggesting that two transgressive-regressive cycles controlled Quaternary sedimentation in the study area.

It is worthy to note that on seismic sections both fill type $\mathrm{E}$ and $\mathrm{F}$ overlie laterally extensive sedimentary deposits with chaotic to transparent internal configurations (Fig. 12). This type of seismic expression is usually associated with debris flow deposits (Posamentier et al. 2000) that predate fill types $\mathrm{E}$ and $\mathrm{F}$.

Fill type $\mathrm{G}$ (Fig. 5g) contains localized migrating depressions accommodating strata bounded by strong positive seismic reflectors. At the flanks, the reflectors geometries suggest wedge-shaped deposits that gently dip and thin away

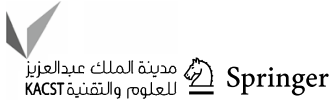



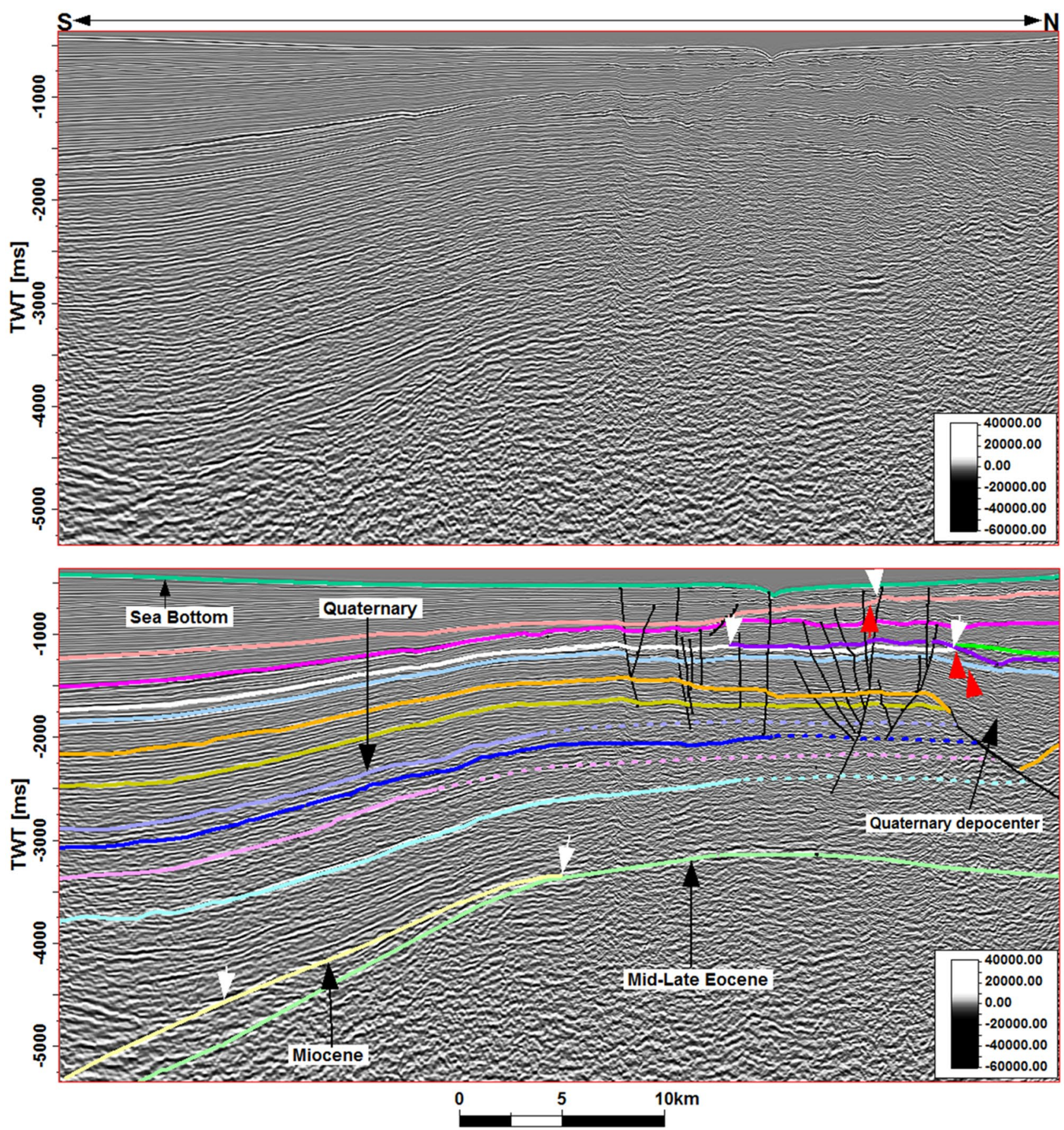

Fig. 8 Uninterpreted and interpreted seismic line TA-11-1003 showing a smooth part of the Mid-Late Miocene reflector whereby the Miocene reflector onlap onto it. Here a palaeodepocenter is observed to the south of the line. Dashed lines show probable stratigraphic positions of the respective reflectors where interpretation could not be done with certainty due to limited seismic resolution. Quaternary sedimentary package is discontinued by several high angle dipping

from the depressions. These depressions are interpreted to indicate palaeochannel systems and the wedges on the flanks are the overbank deposits representing channel levees faults. White arrows show onlap features in two different stratigraphic levels in the Quaternary geology while red arrows show erosional truncations in three different stratigraphic levels in the Quaternary section. The unnamed reflectors have been included just to show depositional configurations/geometries and strata termination patterns between the major reflectors shown in Fig. 3

(Posamentier et al. 2000; Posamentier and Kolla 2003). Strong reflection amplitudes observed within the channels (bounding reflectors of the channel fills) suggest presence of 

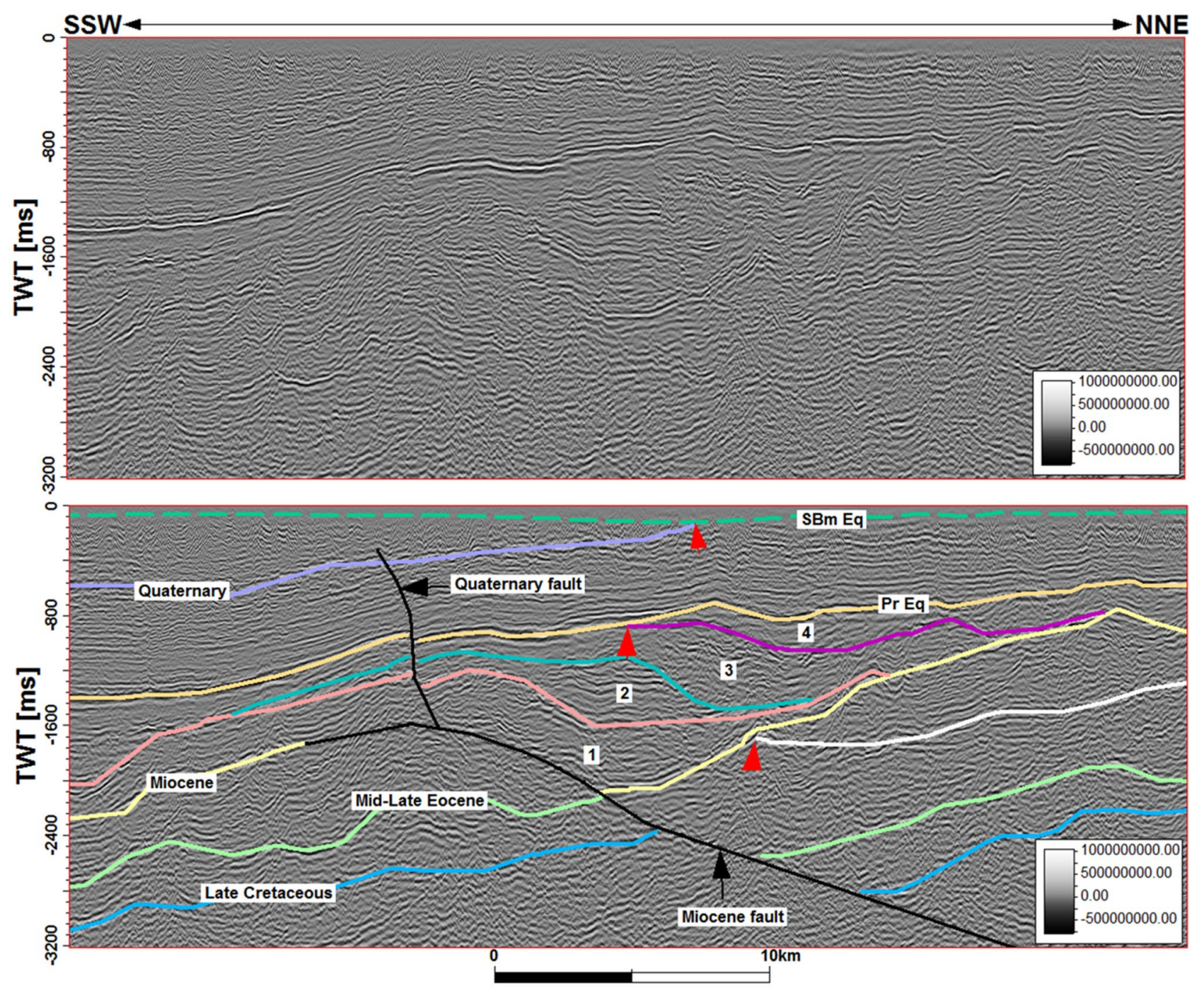

Fig. 9 Uninterpreted and interpreted seismic line 82-12-FPSTM showing Late Cretaceous-Quaternary sedimentary deposits of the offshore Tanga Basin. The Late Cretaceous, Mid-Late Eocene, Miocene and Quaternary reflectors are laterally extensive but have discontinued by faults. Numbers 1-4 show sedimentary packages accommodated in bowl-shaped depressions migrating to the NNE.

coarse sand deposits. Stratigraphically, fill type G overlie fill type F in the Quaternary succession of the Tanga offshore Basin (Fig. 12).

Fill type H (Fig. 5h) has two subunits, the lower strata which onlap onto a base reflector and are followed by clinoforms of the upper subunits. The clinoforms toplap onto the top surface interpreted to mark the Sea Bottom. These onlap and toplap surfaces suggest presence of two unconformities in the youngest part of the Quaternary geology studied in this work. This fill type is seen in the topmost interval of the Quaternary section (Fig. 13). On seismic, fill types $\mathrm{E}-\mathrm{H}$ are discontinued by several high angle dipping chaotic linear features. These features mark Quaternary faults that
$\mathrm{SBm} \mathrm{Eq}$ is an equivalent reflector to the Sea Bottom (dashed line has been used because the reflector could not be followed with certainty due to limited seismic quality). Pr Eq is an equivalent reflector to the bounding reflector of a thick sedimentary succession that overlies the Miocene syn-rift basin fill (Post rift blanket shown in Fig. 6). Red arrows show erosional truncations

deformed the sedimentary system. Overall, fill types E-H show that Late Cretaceous-Quaternary stratigraphy of the Tanga offshore Basin marked by at least 7 unconformities (Fig. 2).

\section{Reflectors and general sesimic expression}

Late cretaceous The Late Cretaceous interval is marked by an undulated, strong positive reflection horizon that is discontinued by moderate-low angle dipping Miocene faults (Figs. 6 and 9). This reflector underlies sedimentary packages having relatively constant thickness with chaotic internal seismic expression (e.g. Figure 6). Part of the superja- 

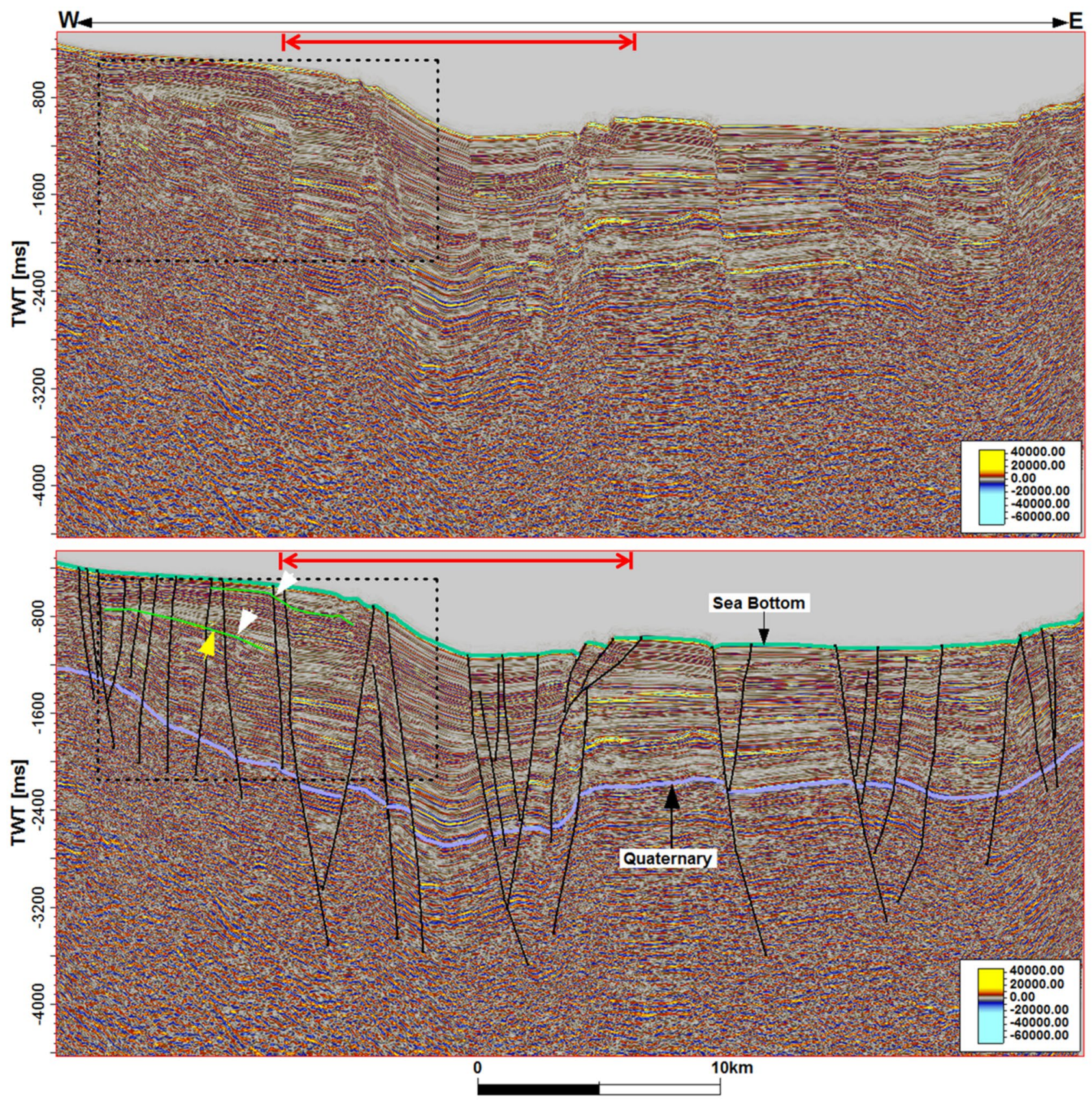

Fig. 10 Uninterpreted and interpreted seismic line TA-11-1018 showing structural elements of the Quaternary stratigraphy. Yellow and white arrows show top lap and onlap surfaces respectively. The Sea Bottom reflector is dissected by several Quaternary faults. Black dashed rectangle shows position of Fig. 11. Red arrow marks the extent of the depression/graben with Quaternary reflector as its bottom boundary cent successions is discontinued by near vertical Quaternary faults (Fig. 6). Undulating nature of the Late Cretaceous reflector indicates that it marks an erosional surface. Packages with uniform thickness suggest dominance of tectonic quiescence during the Late Cretaceous when sedimentation kept pace with basin subsidence.
Mid-late eocene The Mid-Late Eocene interval is marked by an extensive, undulated, weak-medium amplitude reflector through which younger strata onlap (Figs. 7, 8 and 9). The undulations are characterized by up to $15 \mathrm{~km}$ wide structural highs and up to $7 \mathrm{~km}$ wide depressions (Figs. 7 and 9). Some of these structural highs and lows could be reflected 

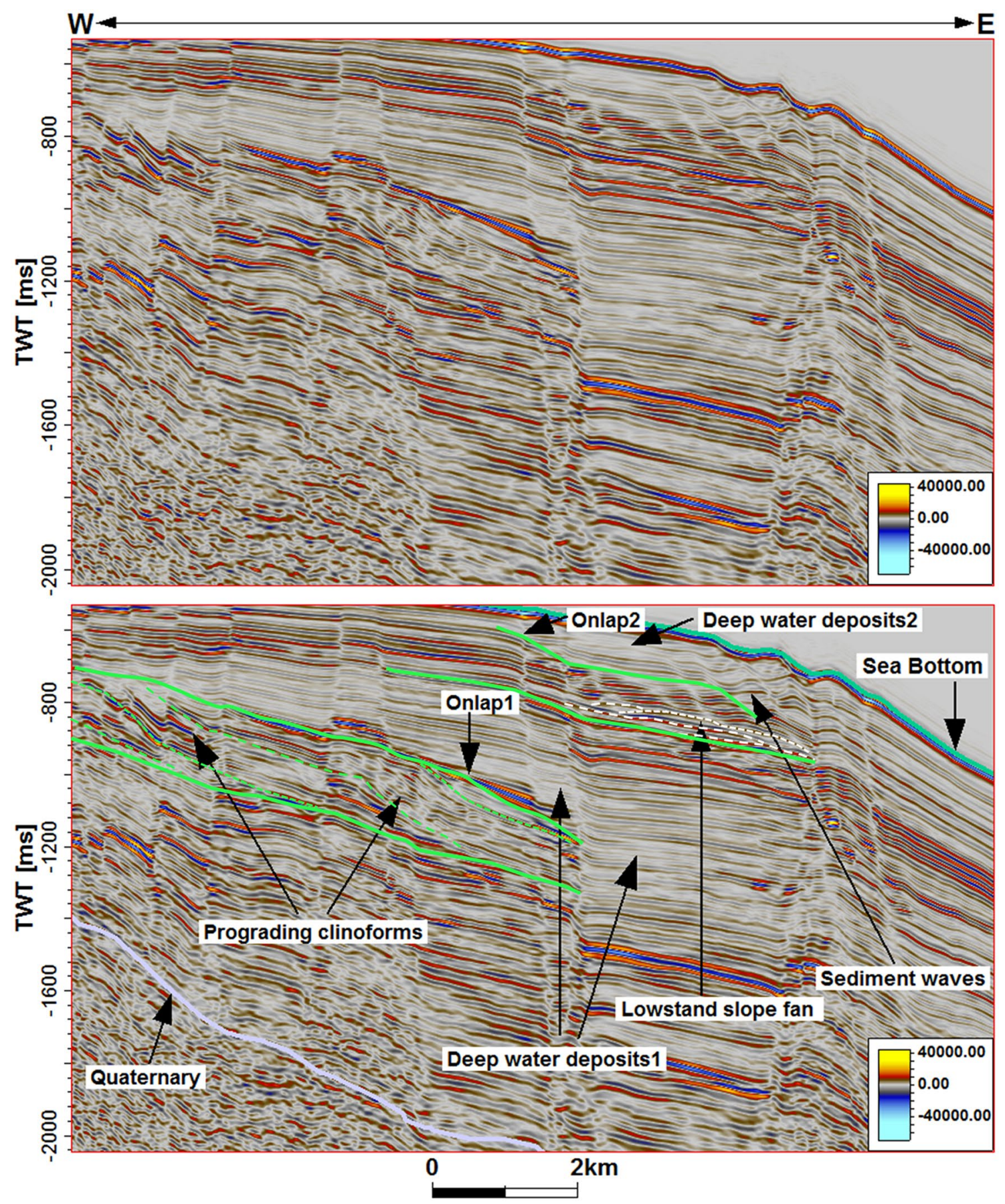

Fig. 11 Uninterpreted and interpreted parts of seismic line TA-111018 showing the Quaternary section which contains two intervals with prograding clinoforms. These intervals are bounded by green solid lines whereby the top boundaries are the onlapping surfaces for

by the overlying sedimentary successions. The reflector is irregular in some places (e.g. Figure 7) and regular in other areas (Fig. 8). Superjacent sedimentary successions are gently dipping to the south and thin progressively toward the north in places where the Mid-Late Eocene reflector is regular (Fig. 8). The reflector is mostly irregular in intervals the immediate superjacent strata. Each interval is roofed by seismic free deposits indicative of high mud to sand ratios. Dashed white lines show layered slope fan deposit. Here the onlap features mark sequence boundaries

where the Miocene faults are present (e.g. Figure 9). Varied properties of the reflector suggest lateral variation and localization of factors that controlled sedimentation during the Eocene. The Mid-Late Eocene reflector is interpreted to mark an unconformity since it is an onlap surface and also because of these irregularities, which are frequently seen in 

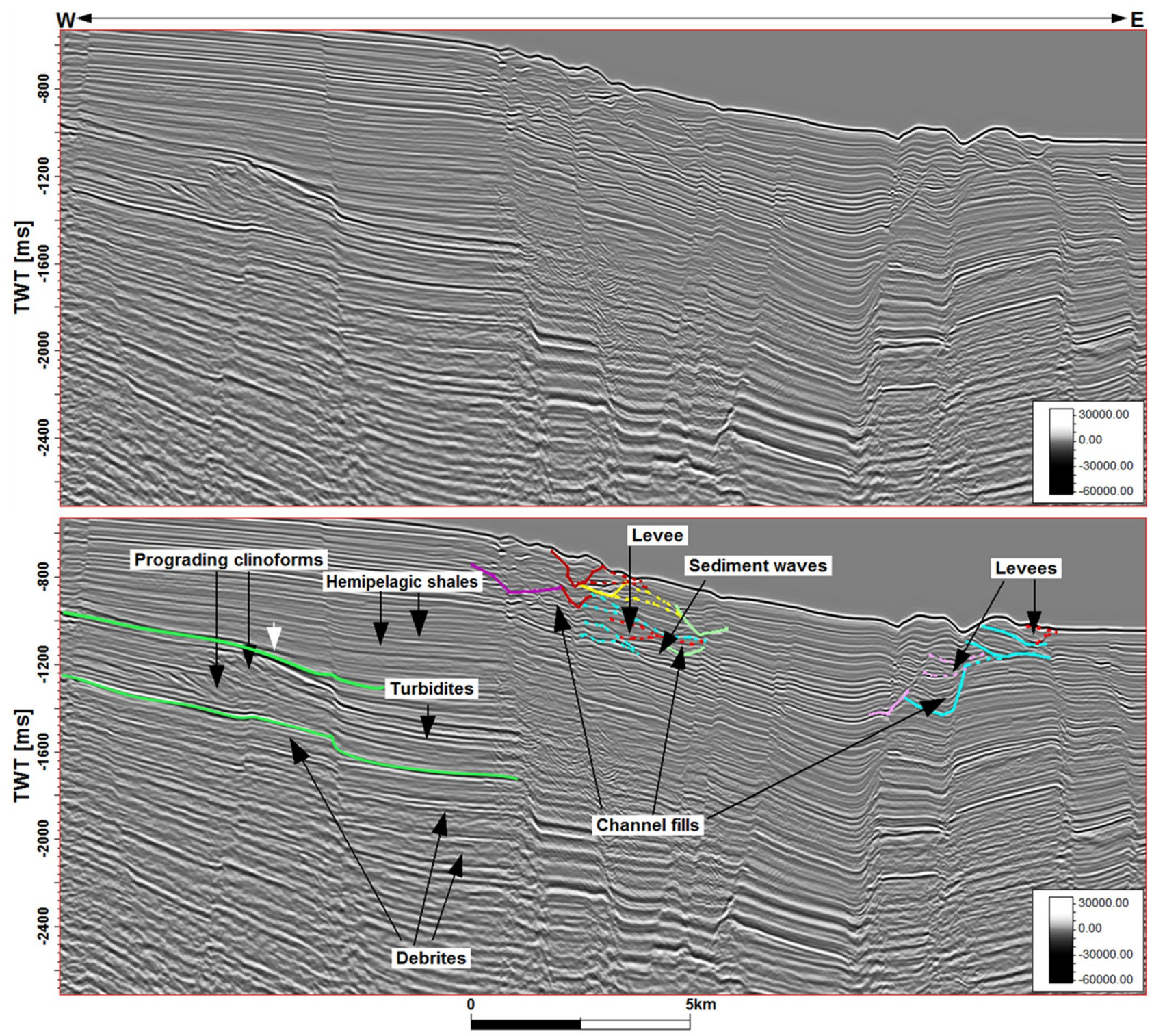

Fig. 12 Uninterpreted and interpreted seismic line TA-08-124. This seismic line shows that the prograding clinoforms overlie sedimentary packages with chaotic to transparent internal configuration indicative of debris flow deposits. Channel systems (colored depressions) and their respective levees (colored dashed lines) are seen further up in this seismic image. White arrow shows an onlap surface interpreted to be a sequence boundary (SB)

the superjacent successions is discontinued by near vertical Quaternary faults (e.g. Figure 6). The wedge-shaped deposits suggest that deposition during the Miocene in the Tanga offshore Basin was largely influenced by tectonic activity which created several depocenters that were filled differently based on interplay between sediment supply and tectonic subsidence. Therefore Miocene successions document both syn-rift sedimentation and post-rift infill of remnant rift topography.

Quaternary Quaternary reflector is also laterally extensive but highly discontinued by near vertical faults. Most of these properties (see descriptions of fill types $\mathrm{C}$ and $\mathrm{D}$ ). Part of 


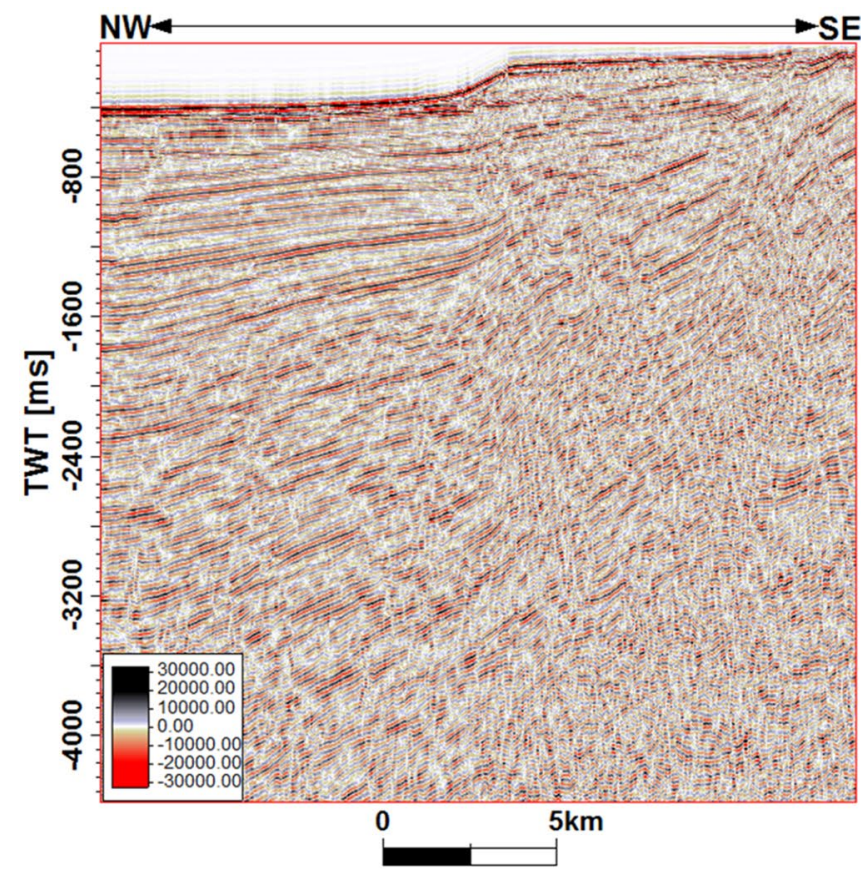

Fig. 13 Uninterpreted and interpreted Seismic line Za9107.STK.1 showing two unconformities up higher in the Quaternary stratigraphy. These unconformities were identified based on the onlap termination

faults are deep rooted along E to ENE, W to WNW, N and S dipping directions (e.g. Figures 8 and 10). The faults which deep in opposing directions flanks and bound a depression on both sides and thus creating accommodation the Quaternary successions (e.g. Figure 10). The prograding clinoforms and their bounding packages (fill types $\mathrm{E}$ and $\mathrm{F}$ ) occur within the Quaternary interval (Figs. 5, 11 and 12). These clinoforms, which indicate basinward deposition (Vail 1987), are overlain by sedimentary fills having characteristic weak, near parallel reflectors with transparent internal configuration. This seismic expression suggests the occurrence of hemipelagic shale deposits (Fonnesu et al. 2020). Channel shaped depressions and their respective overbank packages are visible further up in the Quaternary stratigraphy. The channel systems (Fig. 12) are interpreted to contain coarse sand deposits on the account of their strong reflections. The youngest part of the Quaternary geology contains upslope stepping onlaps blanketed by basinward prograding packages truncated by recent sea bottom sediments (Fig. 13). In the deeper parts of the basin, the youngest part of the Quaternary system consists of sedimentary strata bounded by strong negative reflections (Fig. 7) which suggests the presence of fine grained deposits, possibly deep water shale.

Sea bottom The Sea Bottom is marked by high amplitude extensive reflector discontinued by several Quaternary faults (Fig. 10). The Quaternary channel systems (fill type

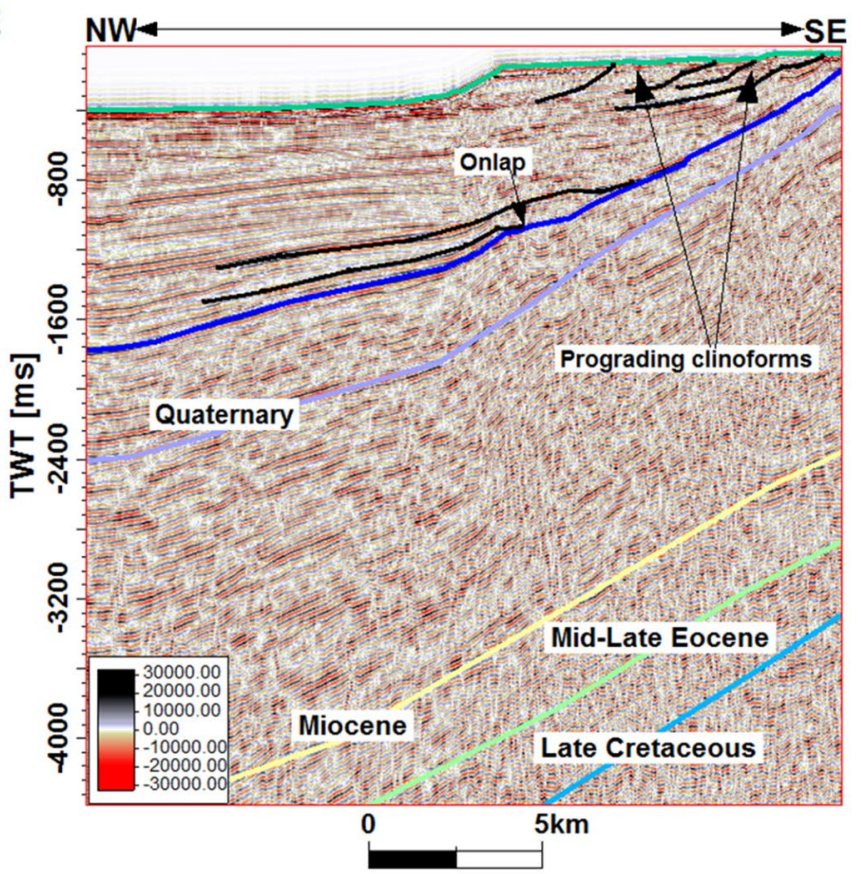

pattern and erosional truncation of the observed prograding clinoforms/sediment wedges

G) coincide with the depressions seen on the Sea Bottom reflectors. These depressions are bounded by the Quaternary faults which dissected the Sea Bottom, thus suggesting that the palaeochannel systems is followed by weak zones generated during faulting.

\section{Discussion}

Sediment supply, basin subsidence, tectonics and climate are the four major factors that influence development of stratal patterns and facies distribution in a sedimentary basin (Vail 1987). The observed sediment distributions and lateral and vertical variations in seismic reflection patterns show that sediment supply was an integral component in the evolution of the Tanga Basin. Occurrence of limestone and salt deposits in the stratigraphy of the Tanzania coastal basins (Kapilima, 2003; Hudson and Nicholas, 2014; Didas, 2016) indicate that deposition was partly influenced by climate variations. However, sediment supply and climatic influences over the examined successions would require further study due to limitations of the available data in analyzing these parameters and thus are left out in this work. The 2D seismic lines analyzed in this study were employed to establish the interplay between the tectonics and sea level fluctuations, especially as this influences the development

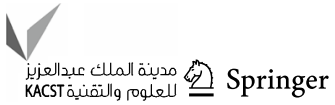


of the late Cretaceous-Quaternary stratigraphy off the coast of Tanga Basin.

Based on sedimentary fill geometries and fault properties, it has been shown that the Late Cretaceous sedimentation took place during tectonic quiescence. This is in agreement with previous works reporting tectonic development of the offshore basins of East Africa (e.g. Franke et al. 2015). The Late Cretaceous erosional surface reported here is thought to be an equivalent of the Albian unconformity (Late Cretaceous unconformity in Fig. 2) reported elsewhere in the offshore settings of East Africa (Mahanjane et al. 2014; Franke et al. 2015; Kiswaka 2015). Block movements which occurred during the Miocene period was followed by faulting that created Miocene depocenters. The associated fault movement, corresponding to Miocene tectonic event (Fig. 2), created sediment sources and triggered gravity flow that eroded part of the Late Eocene interval leading to deposition of thick sedimentary successions in the deeper basinal areas (Fig. 14). These successions are thought to be similar to age equivalent mass transport complexes reported by Sansom (2018) in Mnazi Bay, further south of the study area. The Mnazi Bay Miocene complexes contain hybrid turbidite-contourite deposits formed due to interaction of downslope gravity flows and along shore bottom currents (Sansom 2018). These deposits are characterized by clean deep water sandstone reservoirs with high net-to-gross ratio (e.g. Fonnesu et al. 2020). Major gas discoveries off the coast of East Africa have been made in hybrid turbidite-contourite deposits, examples of which are the Coral and Mamba gas fields in Mozambique (Fonnesu et al. 2020). The presence of these deposits in the Tanga Basin implies occurrence of favorable hydrocarbon reservoirs within the study area. Future researches will focus on the assessment of possible presence of matured source rocks that may have charged the Miocene reservoirs of the Tanga Basin. The Miocene deposits of the Tanga Basin onlap onto the MidLate Eocene reflector in the deeper basinal areas, thus leading to identification of the Mid-Late Eocene unconformity in the study area. The Miocene epoch is reported to have been dominated by extensional regime (Franke et al. 2015).
Fig. 14 An isopach map showing thickness variation between Mid-Late Eocene and Miocene deposits. A general eastward thickening of sedimentary successions observed in this map reflects basinward transportation of sediments by gravity flows during the Miocene period

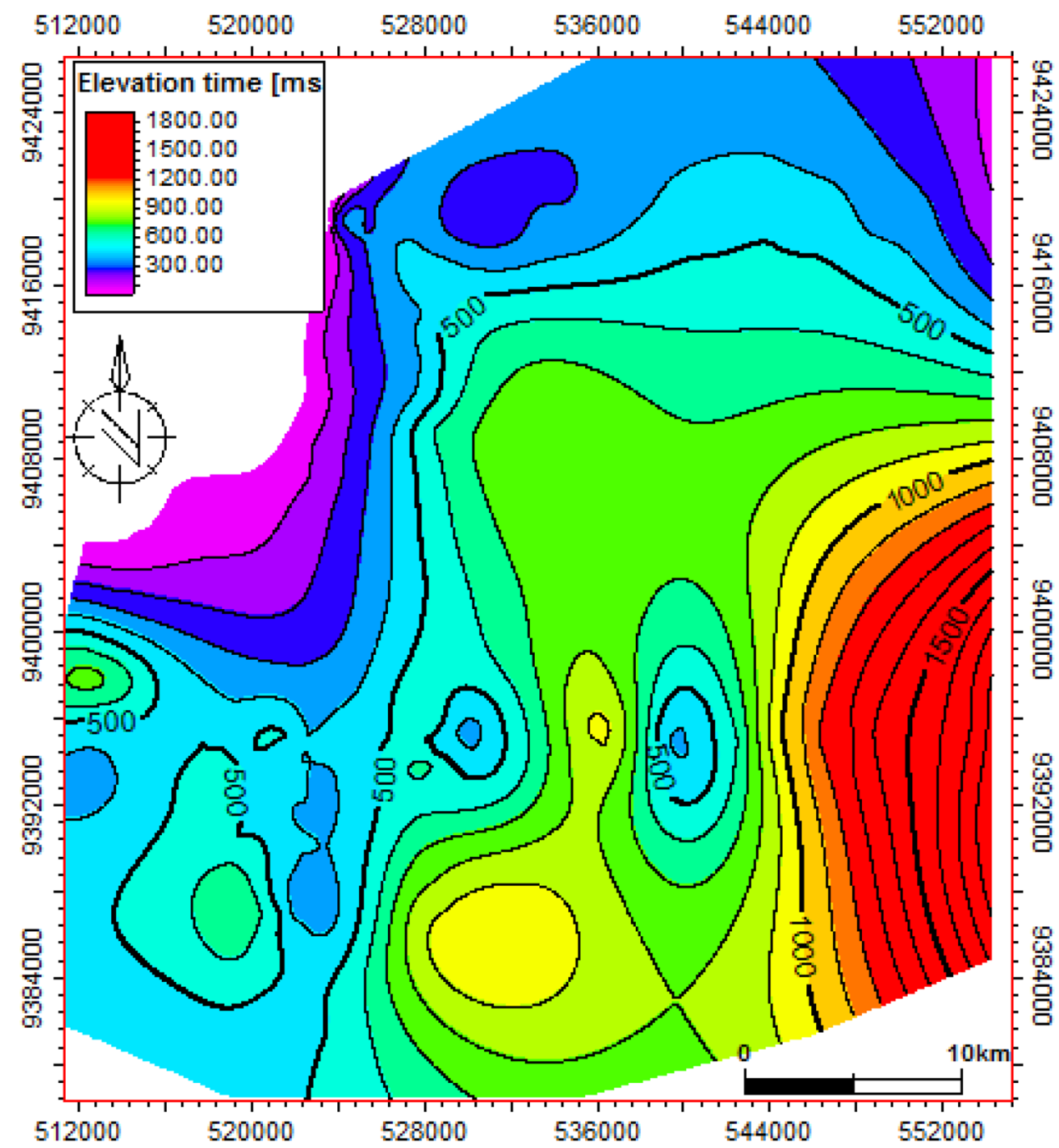


Fig. 15 Quaternary surface map showing a deep graben formed during the Quaternary. Eastern limit of the graben is Pemba, southern limit is Zanzibar, northern limit is the Quaternary fault and the western limit is the Indian Ocean shoreline. Here, a $\mathrm{N}-\mathrm{S}$ to NNE-SSW trend of the basin can be seen

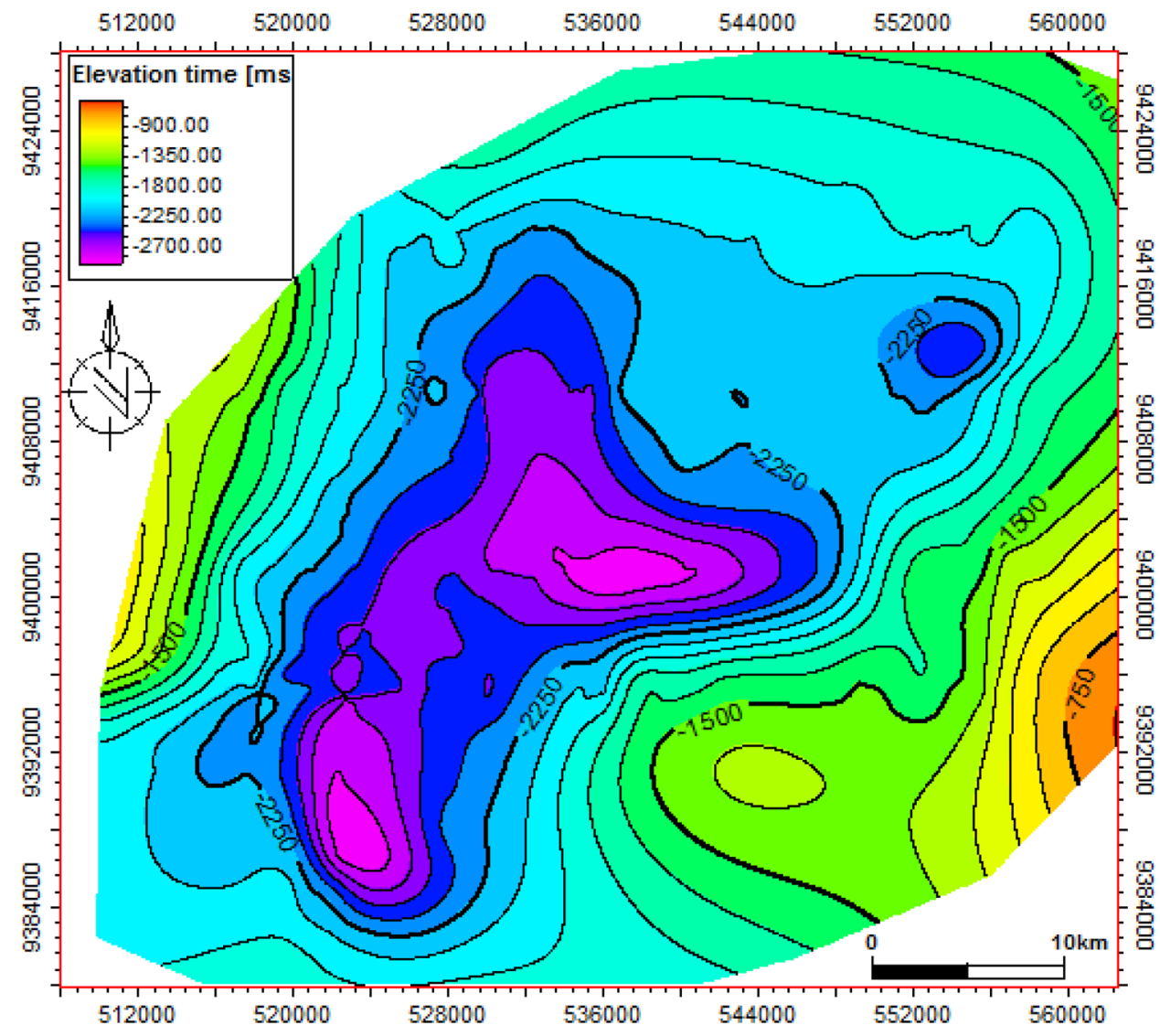

Similar observation is reported herein but with the fact that locations, shapes and sedimentary fills of these basins are shown clearly.

The Quaternary geology of the offshore Tanga Basin has been strongly influenced by the East African Rift system (EARs). This rifting created about $25 \mathrm{~km}$ wide and approximately $2.5 \mathrm{~s}$ two-way travel time (TWT) deep graben during the Quaternary (Fig. 15). The graben which trends N-S to NNE-SSW (Fig. 15) is located between Pemba and the Indian Ocean shoreline. This graben accommodates thick Quaternary sedimentary deposits (Fig. 16). Tentative age assignment suggests that the graben was formed during the Pleistocene epoch. Franke et al. (2015) reported Pliocene and Pleistocene epochs as the periods of rapid rift subsidence and sedimentation in the offshore settings of East Africa, but seismic reflections indicate that the same occurred during Pleistocene and Holocene as it is reflected by two intervals with prograding clinoforms in the Quaternary stratigraphy (Fig. 11).

Two intervals with lowstand system tracts (LST) deposits are seen in the Quaternary part of the studied interval (Fig. 11). Posamentier and Vail (1988) and Posamentier et al. (1991) described two conditions through which prograding clinoform patterns characterizing the LST are deposited in a basin. These conditions are right when (1) the rate of sea level fall is greater than total rate of basin subsidence or the rate of tectonic uplift surpasses the rate of sea level rise, or (2) the depocenter has shifted basinward due to sea level fall. This work and previous researches (e.g. Franke et al., 2015) report rapid rift subsidence, in the offshore basins of East Africa, during the Pleistocene and Holocene epochs marking occurrence of two tectonic events during the Quaternary (Fig. 2). These observations give room for a suggestion that the observed LTS deposits in the Quaternary section were laid down at a time when the total basin subsidence/rate of tectonic uplift was significantly greater than the rate of sea level rise. The LST deposits identified herein overlie intervals that are interpreted to present debris flow deposits; beneath deep water deposits (Figs. 11 and 12). The debrites are seen because as the sea level falls, slope instability occurs causing gravity failures that lead to dominance of the debris flow processes at a time (Hunt and Tucker 1992; Posamentier et al. 2000). Deposition of the Quaternary deep water successions is interpreted to have occurred during intervening periods of tectonic quiescence when the rate of sea level rise was relatively greater than total basin subsidence. These fluctuations suggest that at least two transgressive-regressive cycles occurred during the Quaternary period, and they conform with the Holocene and Pleistocene tectonic events (Fig. 2). 
Fig. 16 An isopach map showing thickness variation of sediments between Quaternary and Sea Bottom reflectors. Thick sedimentary successions have a $\mathrm{N}-\mathrm{S}$ to NNE-SSW orientations conforming to the deep Quaternary graben in Fig. 15

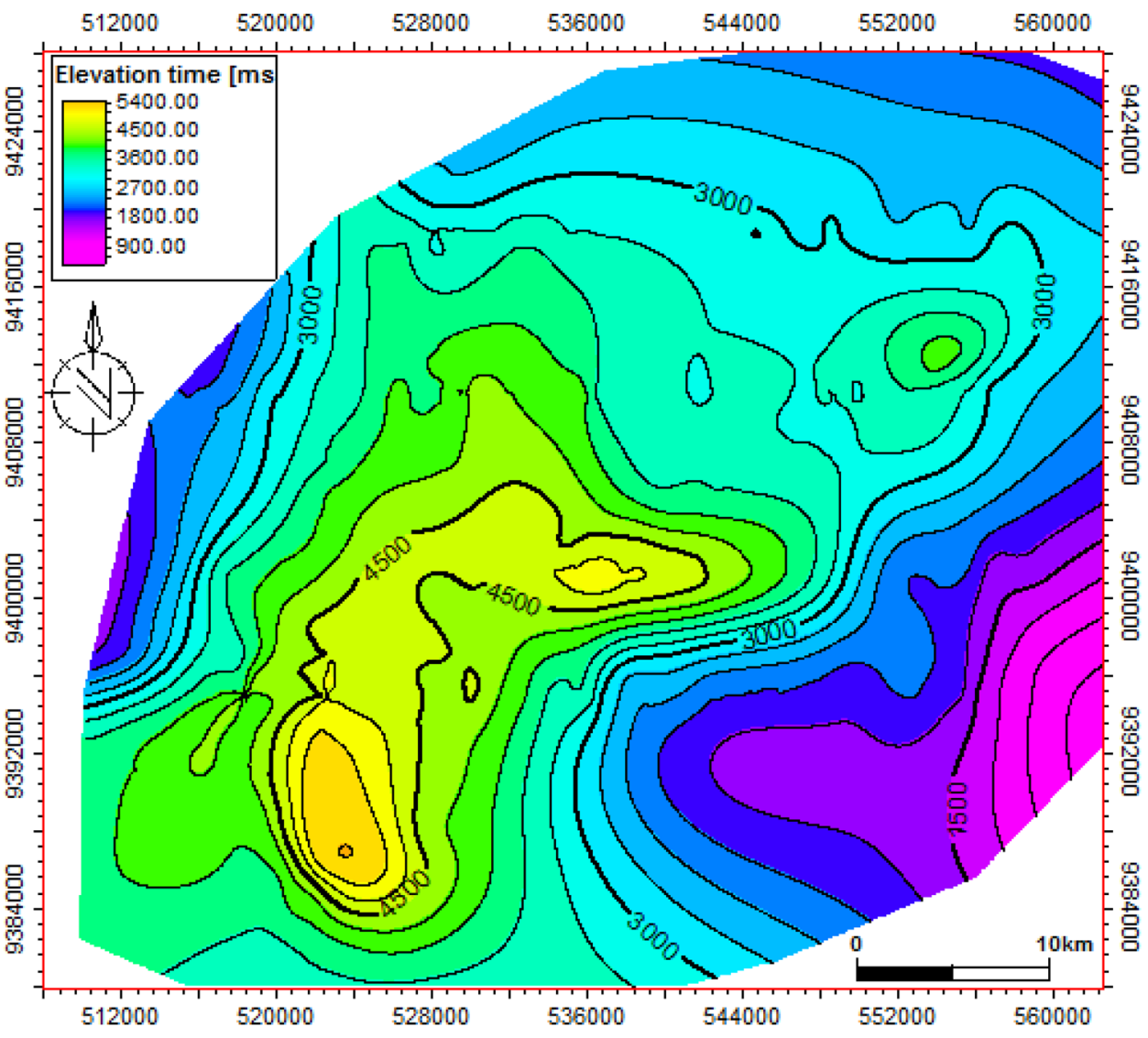

Previous works have reported presence of Mesozoic and Cenozoic clastic deposits, Post-rift Cretaceous regressivetransgressive marine sandstone, slope-turbidite channel sandstones, Upper Cretaceous carbonates, Maastrichtian and Paleocene turbidite deposits (slope channels sandstone and basin floor fan) as the potential reservoirs off the coast of Tanzania (e.g. Brownfield 2016). This work reports presence of potential Miocene reservoirs with high net-to-gross ration as well as delineate two Quaternary intervals with LST deposits indicative of potential lowstand slope fan (Fig. 11). The Quaternary interval studied contains channel sand deposits and overbank turbidites (Fig. 5g). The lowstand slope fan deposits are reported to be key reservoir intervals (Vail 1987). Channel sand deposits and overbank turbidites have also been delineated as potential petroleum reservoirs (Vail 1987). The deep water deposits overlying the LST (Figs. 11 and 12) are interpreted to form potential cap rocks in the area. In this study, the Karoo carbonaceous black shales which have high organic content (e.g. Seward 1922) are believed to be potential source rocks that possibly charged the Miocene and Quaternary reservoir intervals in the Tanga Basin.

Based on Mitchum et al. (1977) and recent works of Kyrkjebø et al. (2004), stratal termination patterns in Figs. 6, 7, 8, 9, 10, 11, 12 and 13 and their simplification in Fig. 5 cartoon show that the studied stratigraphy has at least seven unconformities marking the boundaries between periods of varying tectonic activities, sediments supply and sea level rise. Strata termination patterns discussed here include the onlap, downlap, and toplap (erosional truncation) features (Figs. 6, 7, 8, 9, 10, 11, 12 and 13).

\section{Conclusion}

Two dimensional (2D) seismic images have been analyzed in order to evaluate the Late Cretaceous-Quaternary geology of the Tanga offshore Basin which is characterized by several unconformities. Different depocenter geometries, sedimentary fills, stratal termination patterns and internal seismic reflection attributes indicate that deposition within the basin was mostly influenced by sediments influx, tectonics and sea level variations. Major sediments influx was due to episodic gravity flows triggered by block movements that are linked to periods of extensional tectonics. Example of this is manifested by the Miocene sedimentary successions that have a general basinward thickening trend. These Miocene successions have been interpreted to be characterized by hybrid turbidite-contourite deposits that contain sandstone reservoirs. An interplay 
between tectonics and sea level variations caused two major transgressive-regressive cycles that culminated at the emplacement of lowstand slope fan deposits, channel sand deposits and overbank turbidites that form potential petroleum reservoir rocks in the Quaternary stratigraphy. These reservoir intervals are capped by deep water shales forming potential seal rocks in the area. Both, Miocene and Quaternary reservoir rocks, are interpreted to have been charged by the Karoo black shales. The Quaternary successions are accommodated within a more or less N-S to NNE-SSW trending graben created during the Pleistocene and Holocene tectonic events. The Quaternary graben is bounded by the near vertical Quaternary faults characterized by multiple dip directions.

Acknowledgements The Authors are thankful to the following; Pan African University Life and Earth Sciences Institute (PAULESI) for the award of PhD Scholarship to the first author, the University of Dodoma for granting study leave to the first author, Tanzania Petroleum Development Corporation (TPDC) and Tanzania Petroleum Upstream Regulatory Authority (PURA) for providing all data set used in this work, School of Mines and Geosciences of the University of Dar es Salaam for providing facilities that allowed successful completion of this work, and Japhet Fungo of the University of Dar es Salaam for his contribution that improved Fig. 1.

Funding None.

\section{Declarations}

Conflict of Interest On behalf of all authors, the corresponding author states that there is no conflict of interest.

Open Access This article is licensed under a Creative Commons Attribution 4.0 International License, which permits use, sharing, adaptation, distribution and reproduction in any medium or format, as long as you give appropriate credit to the original author(s) and the source, provide a link to the Creative Commons licence, and indicate if changes were made. The images or other third party material in this article are included in the article's Creative Commons licence, unless indicated otherwise in a credit line to the material. If material is not included in the article's Creative Commons licence and your intended use is not permitted by statutory regulation or exceeds the permitted use, you will need to obtain permission directly from the copyright holder. To view a copy of this licence, visit http://creativecommons.org/licenses/by/4.0/.

\section{References}

Ali M (2020) Three-dimensional structural modelling and source rock evaluation of the quseir formation in the Komombo Basin. Egypt Acta Geol Sin-Engl Edit 94:1619-1634

Ali I, Olatunji S, Nwankwo LI, Akoshile CO, Johnson LM, Edinoc F (2012) Geomagnetic modeling of potential hydrocarbon traps in the lower Niger Delta, Offshore West Africa. Arch Appl Sci Res 4:863-874

Ali M, Abdelhady A, Abdelmaksoud A, Darwish M, Essa MA (2019a) 3D static modeling and petrographic aspects of the Albian/
Cenomanian Reservoir, Komombo Basin, Upper Egypt. Nat Resour Res 29:1259-1281

Ali M, Abdelmaksoud A, Essa MA, Abdelhady A, Darwish M (2019b) 3D structural, facies and petrophysical modeling of $\mathrm{C}$ member of Six Hills Formation, Komombo Basin, Upper Egypt. Nat Resour Res 29:2575-2597

Armitage DA, McHargue T, Fildani A, Graham SA (2012) Postavulsion channel evolution: Niger delta continental slope Nigeria Avulsions. AAPG Bull 96:823-843

Bastia R, Radhakrishna M, Srinivas T, Nayak S, Nathaniel D, Biswal T (2010) Structural and tectonic interpretation of geophysical data along the Eastern Continental Margin of India with special reference to the deep water petroliferous basins. J Asian Earth Sci 39:608-619

Becker K, Franke D, Schnabel M, Schreckenberger B, Heyde I, Krawczyk C (2012) The crustal structure of the southern Argentine margin. Geophys J Int 189:1483-1504

Blaich O, Faleide J, Tsikalas F, Lilletveit R, Chiossi D, Brockbank P, Cobbold P (2010) Structural architecture and nature of the continent-ocean transitional domain at the Camamu and Almada basins (NE Brazil) within a conjugate margin setting. Geological Society of London 7:867-883

Bosellini A (1986) East Africa continental margins. Geology 14:76-78

Braathen A, Bælum K, Maher H Jr, Buckley SJ (2012) Growth of extensional faults and folds during deposition of an evaporitedominated half-graben basin; the Carboniferous Billefjorden Trough, Svalbard. Norw J Geol 91:137-161

Brownfield ME (2016) Assessment of Undiscovered Oil and Gas Resources of the Tanzania Coastal Province, East Africa. In: Brownfiel ME (compiler), Geologic Assessment of Undiscovered Hydrocarbon Resources of Sub-Saharan Africa. U.S. Geological Survey Digital Data Series 69-GG, chap 12, pp 12.

Busygin B, Nikulin S, Zatsepin E, Garkusha I (2010) The methodology of operative prognosis of hydrocarbons by gravity-magnetic and space data. Nat Min Univ Dniepropetrovsk, Ukrain 32:26-28

Dapeng Z (2001) Seismic structure and origin of hotspots and mantle plumes. Earth Planet Sci Lett 192:251-265

Dehler SA, Welford JK (2012) Variations in rifting style and structure of the Scotian margin, Atlantic Canada, from 3D gravity inversion. Geol Soc Lond Spec Publ 369:289-300

Delvaux D (2001) Karoo rifting in western Tanzania: precursor of Gondwana break-up. Contrib Geol Paleontol Gondwana Honor Helmut Wopfner, Cologne, Geol Inst Univ Cologne, 111-125

Didas MM (2016) Geophysical investigation of the subsurface structures of the Mandawa Basin, southeast coastal Tanzania. M.Sc. thesis, University of Dar es Salaam

Ebinger C, Djomani YP, Mbede E, Foster A, Dawson JB (1997) Rifting archaean lithosphere: the Eyasi-Manyara-Natron rifts, East Africa. J Geol Soc 154:947-960

Fonnesu M, Palermo D, Galbiati M, Marchesini M, Bonamini E, Bendias D (2020) A new world-class deep-water play-type, deposited by the syndepositional interaction of turbidity flows and bottom currents: the giant Eocene Coral Field in northern Mozambique. Mar Pet Geol 111:179-201

Foster A, Ebinger C, Mbede E, Rex D (1997) Tectonic development of the northern Tanzanian sector of the East African Rift System. J Geol Soc 154:689-700

Franke D, Jokat W, Ladage S, Stollhofen H, Klimke J, Lutz R, Schreckenberger B (2015) The offshore East African Rift System: structural framework at the toe of a juvenile rift. Tectonics 34:2086-2104

Houghton P, Nuttall P, Cvetkovic M, Mazur S (2014) The role of potential fields as an early dataset to improve exploration in frontier areas. First Break 32:79-85

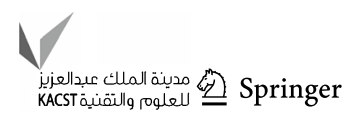


Hudson WE, Nicholas CJ (2014) The pindiro group (Triassic to Early Jurassic Mandawa Basin, southern coastal Tanzania): Definition, palaeoenvironment, and stratigraphy. J Afr Earth Sc 92:55-67

Hunt D, Tucker ME (1992) Stranded parasequences and the forced regressive wedge systems tract: deposition during base-level fall. Sed Geol 81:1-9

IEA (2017) World Energy Outlook 2017: Flagship Report. https:// www.iea.org/reports/world-energy-outlook-2017\#a-new-orderfor-global-gas-markets. Accessed 13 February 2020

Jacques JM, Parsons ME, Price AD, Schwartz DM (2003) Improving geologic understanding with gravity and magnetic data: examples from Gabon, Nigeria and the Gulf of Mexico. First Break 21:57-62

Jacques JM, Price AD, Bain JE (2004) Digital integration of potential fields and geologic data sets for plate tectonic and basin dynamic modeling - the first step toward identifying new play concept in the Gulf of Mexico. Lead Edge 23:384-389

Kapilima S (2003) Tectonic and sedimentary evolution of the coastal basin of Tanzania during the Mesozoic times. Tanzan J Sci 29:1-16

Kent PE, Hunt JA, Johnstone DW (1971) The geology and geophysics of coastal Tanzania. Inst Geolo Sci Geophys Pap 6:1-101

Key RM, Smith RA, Smelror M, Sæther OM, Thorsnes T, Powell JH, Njange F, Zandamela EB (2008) Revised lithostratigraphy of the mesozoic-cenozoic succession of the onshore Rovuma Basin, northern coastal Mozambique. J Afr Earth Sc 111:89-108

Kiswaka EB, Felix M (2020) Permo-Triassic sedimentary fills and tectonic phases off Mid Norway: seismic investigation of the Trøndelag Platform. Norw J Geol 1:100

Kiswaka EB (2015) 2D Seismic Interpretation, Basin and Petroleum System Modelling of the Block 5 Offshore Southern Tanzania. Dissertation, Norwegian University of Science and Technology

Kreuser T, Wopfner H, Kaaya CZ, Markwort S, Semkiwa PM, Aslandis $P$ (1990) Depositional evolution of permo-triassic karoo basins in Tanzania with reference to their economic potential. J Afr Earth Sc 10:151-167

KyrkjebØ R, Gabrielsen RH, Faleide JI (2004) Unconformities related to the Jurassic-Cretaceous synrift-post-rift transition of the northern North Sea. J Geol Soc 161:1-17

Lentini M, Fraser S, Sumner H, Davies RJ (2010) Geodynamics of the central South Atlantic conjugate margins: implications for hydrocarbon potential. Pet Geosci 16:217-229

Macgregor D (2015) History of the development of the East African Rift System: a series of interpreted maps through time. J Afr Earth Sc 101:232-252

Magohe SP (2019) Preliminary palynology of the Karoo equivalent Tanga beds, coastal Tanzania: insights on preservation, age and depositional environments. Tanzan J Sci 45:392-404

Mahanjane ES (2014) The davie fracture zone and adjacent basins in the offshore mozambique margin-A new insights for the hydrocarbon potential. Mar Pet Geol 57:561-571

Mbede EI (1991) The sedimentary basins of Tanzania-reviewed. J Afr Earth Sc 13:291-297

Mickus K, Stern R, Keller G, Anthony E (2009) Potential field evidence for a volcanic rifted margin along the Texas Gulf Coast. Geology 37:387-390

Mitchum Jr RM, Vail PR, Thompson III S (1977) Seismic stratigraphy and global changes of sea level: Part 2. The depositional sequence as a basic unit for stratigraphic analysis: Section 2. Application of seismic reflection configuration to stratigraphic interpretation

Mkuu D (2018) Palynological, palynofacies, thermal maturity and burial modelling analyses of the Cretaceous to Cenozoic sediments from a series of Tanzanian onshore and offshore boreholes. Dissertation, University Of Southampton

Mvile BN, Abu M, Osinowo OO, Marobhe IM, Olayinka AI (2020) An overview of the geology of Tanga onshore Basin: implication for hydrocarbon potential, Tanzania, East Africa. Journal of Sedimentary Environments 5:267-277

Nottvedt A, Gabrielsen RH, Steel RJ (1995) Tectonostratigraphy and sedimentary architecture of rift basins, with reference to the northern North Sea. Mar Pet Geol 12:881-901

Pángaro F, Ramos V (2012) Paleozoic crustal blocks of onshore and offshore central Argentina: new pieces of the southwestern Gondwana collage and their role in the accretion of Patagonia and the evolution of Mesozoic south Atlantic sedimentary basins. Mar Pet Geol 37(1):162-183

Posamentier HW, Kolla V (2003) Seismic geomorphology and stratigraphy of depositional elements in deep-water settings. J Sediment Res 73:367-388

Posamentier HW, Vail RR (1988) Eustatic controls on clastic deposition II - sequence and systems tracts models. Sea level changes - an integral approach. Soc Econ Paleontol Mineral Spec Publ 42:125-154

Posamentier HW, Erskine RD, Mitchum RM (1991) Models for submarine-fan deposition within a sequence-stratigraphic framework. Seismic facies and sedimentary processes of submarine fans and turbidite systems. Springer, New York, pp 127-136

Posamentier HW, Wisman PS, Plawman T (2000) Deep Water Depositional Systems-Ultra Deep Makassar Strait Indonesia. In: Weimer Paul (ed) GCSSEPM foundation 20th annual research conference deep-water reservoirs of the world. Society of economic paleontologists and mineralogists, pp 3-6

Prosser S (1993) Rift-related linked depositional systems and their seismic expression. Tectonics and seismic sequence stratigraphy. Geolo Soc London, Special Publ 71:35-66

Ravnås R, Bondevik K (1997) Architecture and controls on BathonianKimmeridgian shallow-marine synrift wedges of the OsebergBrage area, northern North Sea. Basin Res 9:197-226

Ravnås R, Steel RJ (1998) Architecture of marine rift-basin successions. AAPG Bull 82:110-146

Roberts EM, Stevens NJ, O'Connor PM, Dirks PHG, Gottfried MD, Clyde WC, Hemming S (2012) Initiation of the western branch of the East African Rift coeval with the eastern branch. Nat Geosci 5:289-294

Sansom P (2018) Hybrid turbidite-contourite systems of the Tanzanian margin. Pet Geosci 24:258-276

Seward AC (1922) On a small collection of fossil plants from Tanganyika Territory. Geol Mag 59:385-392

TPDC (1992) Tanzania Petroleum Exploration Potential. Tanzania Petroleum Development Corporation (TPDC), internal report

Uruski C (2010) New Zealand's deepwater frontier. Mar Pet Geol 27:2005-2026

Vail PR (1987) Seismic stratigraphy interpretation procedure. In: Bally AW (ed) Atlas of seismic stratigraphy. AAPG studies in Geology, pp 1-10

Wescott WA, Diggens JN (1998) Depositional history and stratigraphical evolution of the Sakamena Group(Middle Karoo Supergroup) in the southern Morondava Basin, Madagascar. J Afr Earth Sc 27:461-479

Wopfner H (2002) Tectonic and climatic events controlling deposition in Tanzanian Karoo basins. J Afr Earth Sc 34:167-177

Zhixin W, Zhaoming W, Chengpeng S, Zhengjun H, Xiaobing L (2015) Structural architecture differences and petroleum exploration of passive continental margin basins in east Africa. Pet Explor Dev 42:733-744

Zongying Z, Shujun L, Wenlong D (2013) Hydrocarbon potential in the key basins in the East Coast of Africa. Pet Explor Dev 40:582-591

Publisher's Note Springer Nature remains neutral with regard to jurisdictional claims in published maps and institutional affiliations. 